Check for updates

Cite this: RSC Adv., 2017, 7, 27177

\title{
Synthesis of aluminum complexes supported by 2- (1,10-phenanthrolin-2-yl)phenolate ligands and their catalysis in the ring-opening polymerization of cyclic esters $\uparrow$
}

\begin{abstract}
Xiang-Xin Zheng a and Zhong-Xia Wang (D) *ab
A series of aluminum complexes supported by 2-(1,10-phenanthrolin-2-yl)phenolate ligands were synthesized and characterized. The reaction of 0 -bromophenol with $n$-butyllithium followed by nucleophilic addition to the phenanthroline and oxidation process gave the ligand precursors 2-(1,10phenanthrolin-2-yl)phenol derivatives $1 a-1 d$. Treatment of $1 a-1 d$ with an equiv. of $A_{l} R_{3}\left(R=E t, B u^{i}\right)$ afforded the corresponding aluminum aryloxides $2 a-2 e$. Treatment of $2 b$ with 2 equiv. of benzyl alcohol formed complex 2f. All new compounds were characterized by ${ }^{1} \mathrm{H}$ and ${ }^{13} \mathrm{C} N M R$ spectroscopy and elemental analyses. The structure of complex $2 \mathrm{c}$ was further characterized by single crystal $\mathrm{X}$-ray diffraction techniques. Complexes $2 \mathrm{a}-2 \mathrm{e} / \mathrm{BnOH}$ and $2 \mathrm{f}$ were active to catalyze the ring-opening polymerization of $\varepsilon$-caprolactone, leading to polycaprolactone with good molecular weight control and relatively narrow molecular weight distribution. Complexes $2 \mathrm{a}-2 \mathrm{e} / \mathrm{BnOH}$ and $2 \mathrm{f}$ catalyzed the polymerization of rac-lactide and $2 b, 2 c, 2 e$ and $2 f$ were demonstrated to lead to isotactic enriched polylactides. The above catalysts also catalyzed the ROP of rac- $\beta$-butyrolactone and led to atactic poly(hydroxybutyrate). Complex $2 f$ also catalyzed block copolymerization of the cyclic esters to form PCL- $b-\mathrm{PHB}, \mathrm{PCL}-b-\mathrm{PLA}$, and PHB-b-PLA block copolymers.
\end{abstract}

Received 4th April 2017

Accepted 17th May 2017

DOI: $10.1039 / c 7 r a 03831 c$

rsc.li/rsc-advances comparison to other polymers. ${ }^{1,3}$ Poly( $\beta$-hydroxybutyrate) (PHB) as an environmentally friendly polymer material offers many advantages over traditional petrochemically derived plastics. For example, it possesses better physical properties than polypropylene for food packaging applications and is nontoxic and biodegradable. PLA and PCL are generally synthesized by the ring-opening polymerization (ROP) of corresponding cyclic esters initiated by metal complexes. PHB is mainly produced using bacterial fermentation techniques from renewable

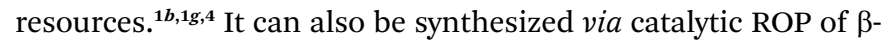
butyrolactone ( $\beta-\mathrm{BL})$. The metal complexes for the ROP of the cyclic esters include alkali metals, ${ }^{5}$ alkaline-earth metals, ${ }^{6}$ group IIIA metals, ${ }^{7}$ group IVA metals, ${ }^{8}$ rare earth metals, ${ }^{9}$ and transition metals ${ }^{10}$ complexes, etc. However, different catalysts can lead to the polymers with different molecular weights, polydispersity indices, and stereo-microstructures. Hence search for new catalysts for synthesis of the polymers is still an important topic. In the previous studies on metal catalysts for the ROP of cyclic esters, aluminum complexes have attracted considerable attention due to oxophilicity and Lewis acidity of the metal center. Numerous $\mathrm{Al}$ complexes bearing a range of multidentate ligands including NO, ONO, NNO, ONNO, and NNNN frameworks have been evaluated. ${ }^{11}$ We reported several aluminum complexes bearing pyridine- or quinoline-based NNO-chelate ligands and demonstrated them to be able to
CAS Key Laboratory of Soft Matter Chemistry, Hefei National Laboratory for Physical Sciences at Microscale, Department of Chemistry, University of Science and Technology of China, Hefei, Anhui 230026, People's Republic of China. E-mail: zxwang@ustc.edu. cn; Tel: +8655163603043

${ }^{b}$ Collaborative Innovation Center of Chemical Science and Engineering (Tianjin), Tianjin 300072, P. R. China

$\dagger$ Electronic supplementary information (ESI) available: Copies of MALDI-TOF mass spectra of PLA and PHB, NMR spectra of polymers and ${ }^{1} \mathrm{H}$ and ${ }^{13} \mathrm{C}$ NMR spectra of ligand precursors 1a-1d and complexes 2a-2f. CCDC 1541685. For ESI and crystallographic data in CIF or other electronic format see DOI: 10.1039/c7ra03831c 
catalyze the ROP of $\varepsilon$-caprolactone $(\varepsilon-\mathrm{CL})$ in the presence of benzyl alcohol. ${ }^{\mathbf{s}, \mathbf{1 2}}$ However, the complexes were inactive towards the ROP of rac-lactide ( $r a c$-LA) in the presence or absence of $\mathrm{BnOH}$. Based on our previous work and the results reported in literatures, ${ }^{7 \boldsymbol{k}, \boldsymbol{l , \boldsymbol { s } , \mathbf { 1 2 }}}$ we designed and synthesized aluminum complexes supported by 2-(1,10-phenanthrolin-2-yl) phenolate ligands and found these complexes to be active catalysts in the ROP of $r a c$-LA, $\varepsilon$-CL and $r a c-\beta$-BL. Here we report the results.

\section{Results and discussion}

\section{Synthesis and characterization of complexes $2 \mathrm{a}-2 \mathrm{f}$}

Synthetic routes of the ligand precursors and the complexes are summarized in Scheme 1. 2-(1,10-Phenanthrolin-2-yl)phenol derivatives 1a-1d were synthesized according to improved literature procedures and characterized by ${ }^{1} \mathrm{H}$ and ${ }^{13} \mathrm{C}$ NMR spectroscopy and elemental analysis. ${ }^{13}$ Reaction of 1a-1d with $\mathrm{AlEt}_{3}$ in toluene at room temperature afforded complexes 2a$\mathbf{2 d}$, respectively. 2e was similarly prepared by treatment of $\mathbf{1 b}$ with triisobutylaluminum in toluene. $2 \mathrm{f}$ was obtained via reaction of $\mathbf{1 b}$ with 1.1 equiv. of $\mathrm{AlEt}_{3}$ followed by in situ alcoholysis of the resultant complex with 2 equiv. of $\mathrm{BnOH}$ at room temperature. Complexes $\mathbf{2 a - 2 d}$ are soluble in toluene and can be crystallized from the toluene solutions. Complex $2 \mathrm{f}$ was crystallized from a diethyl ether solution. Complexes $\mathbf{2 a - 2 f}$ were characterized by ${ }^{1} \mathrm{H}$ and ${ }^{13} \mathrm{C}$ NMR spectroscopy and elemental analyses. The analytical results are accordant with their respective formula. The ${ }^{1} \mathrm{H}$ NMR spectrum of each of $2 \mathbf{a}-2 \mathbf{e}$ exhibits two sets of $\mathrm{Al}-\mathrm{R}$ signals, which correspond two $\mathrm{Al}-\mathrm{R}$ groups in different chemical environments. This might result from the fact that the phenanthroline ring and the phenolic ring are noncoplanar. The ${ }^{1} \mathrm{H}$ NMR spectrum of complex $2 \mathbf{f}$ exhibits two sets of $\mathrm{Al}-\mathrm{OCH}_{2} \mathrm{Ph}$ signals due to similar reason. But we cannot rule out the possibility of a dimeric structure. Attempts to grow its single crystals for X-ray diffraction analysis were unsuccessful. Complex 2c was further characterized by single crystal X-ray diffraction. The ORTEP drawing is presented in Fig. 1, along with selected bond lengths and angles. In the molecule, the aluminum atom is five-coordinate and the coordination geometry of the aluminum atom can be best described as a distorted trigonal bipyramid. The N1Al1C37C39 atoms are approximately coplanar, sum of the angles at aluminum center being $357.68^{\circ}$. The axial positions are occupied by $\mathrm{N} 2$ and $\mathrm{O} 1$ atoms, the angle of $\mathrm{O}(1)-\mathrm{Al}(1)-\mathrm{N}(2)$ being $161.86(13)^{\circ}$. This angle is smaller than corresponding ones in enolato aluminum complexes $\left[\mathrm{Al}\left(\mathrm{Me}_{2}\right)\left\{\mathrm{OC}\left(\mathrm{Bu}^{t}\right)=\mathrm{CHP}\left(\mathrm{Ph}_{2}\right)=\mathrm{N}\left(8-\mathrm{C}_{9} \mathrm{H}_{6} \mathrm{~N}\right)\right\}\right]$ $\left[168.01(14)^{\circ}\right]$ and $\left[\mathrm{Al}\left(\mathrm{Me}_{2}\right)\left\{\mathrm{OC}(\mathrm{Me})=\mathrm{CHC}(\mathrm{Me})=\mathrm{N}\left(8-\mathrm{C}_{9} \mathrm{H}_{6} \mathrm{~N}\right)\right\}\right]$ $\left[164.67(8)^{\circ}\right],{ }^{8 c}$ and larger than that in bipyridine-phenolate

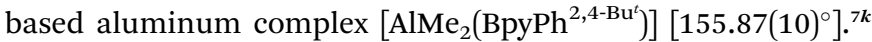
The Al1-N1 distance of 2.065(2) $\AA$ is shorter than that of Al1-N3 $[2.183(3) \AA]$, and both are within normal range for a fivecoordinate aluminum complex. ${ }^{7 k, 8 c}$ The Al1-O1 distance of $1.813(2) \AA$ is comparable to that in $\left[\mathrm{AlMe}_{2}\left(\mathrm{BpyPh}^{2,4-\mathrm{Bu}^{t}}\right)\right]$ $[1.819(2) \AA] .^{. k}$

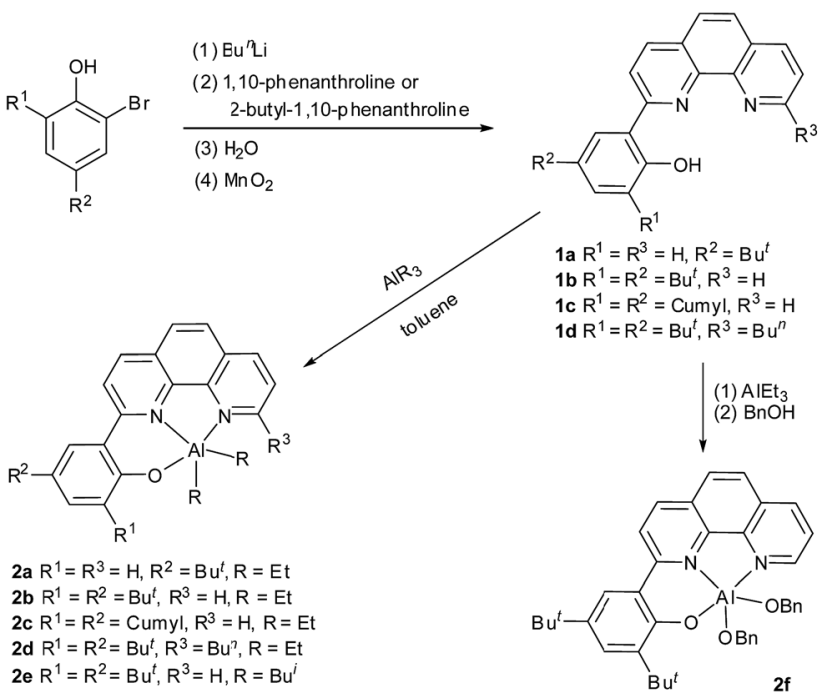

Scheme 1 Synthesis of ligand precursors $1 a-1 d$ and complexes $2 a-2 f$.

The ring-opening polymerization of $\varepsilon$-caprolactone

The ROP of $\varepsilon$-CL in toluene using $\mathbf{2 a - 2 f}$ as the catalysts has been conducted as shown in Table 1. Each of complexes $2 \mathbf{a}-\mathbf{2 e}$ is active for the ROP of $\varepsilon$-CL in the presence of $\mathrm{BnOH}$, and complex 2f is active without requirement of $\mathrm{BnOH}$. In the presence of $\mathrm{BnOH}$, complex $\mathbf{2 b}$ exhibits highest activity. It led to $99 \%$ monomer conversion of 100 equiv. of $\varepsilon$-CL in $1 \mathrm{~h}$ at $50{ }^{\circ} \mathrm{C}$. Complexes $2 \mathrm{c}$ and $2 \mathrm{e}$ exhibited close catalytic activity to each other, but both are a little lower than complex $\mathbf{2 b}$ under the same conditions. Complexes $2 \mathbf{a}$ and $2 \mathbf{2 d}$ showed the lowest activity in this series. Complex $2 \mathbf{f}$ is more active than $\mathbf{2 b}$. For example, $2 \mathbf{f}$ catalyzed 100 equiv. of $\varepsilon$-CL to reach $99 \%$ monomer conversion in $1.5 \mathrm{~h}$ at $25^{\circ} \mathrm{C}$; whereas $2 \mathrm{~b}$ drove 100 equiv. of $\varepsilon$-CL to only $89.3 \%$ monomer conversion in $1.5 \mathrm{~h}$ at $25{ }^{\circ} \mathrm{C}$. An approximate catalytic activity order is $2 \mathrm{f}>2 \mathrm{~b}>\mathbf{2 e} \approx 2 \mathrm{c}>\mathbf{2 d}, \mathbf{2 a}$.

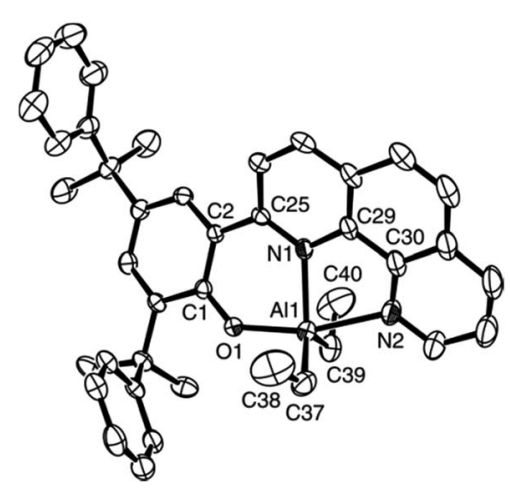

Fig. 1 ORTEP drawing (20\% probability) of complex 2 c. Selected bond lengths (Å) and angles (deg): $\mathrm{Al}(1)-\mathrm{O}(1)$ 1.813(2), $\mathrm{Al}(1)-\mathrm{C}(37) 1.936(4)$, $\mathrm{Al}(1)-\mathrm{C}(39)$ 1.941(4), Al(1)-N(1) 2.065(2), Al(1)-N(2) 2.183(3), O(1)-C(1) 1.301(3); $O(1)-A l(1)-C(37) \quad 95.59(13), \quad O(1)-A l(1)-C(39) \quad 102.08(13)$, $\mathrm{C}(37)-\mathrm{Al}(1)-\mathrm{C}(39)$ 125.03(18), O(1)-Al(1)-N(1) 86.64(10), C(37)-Al(1)$\mathrm{N}(1) \quad 116.42(15), \quad \mathrm{C}(39)-\mathrm{Al}(1)-\mathrm{N}(1) \quad 116.23(14), \quad \mathrm{O}(1)-\mathrm{Al}(1)-\mathrm{N}(2)$ 161.86(13), C(37)-Al(1)-N(2) 87.96(14), C(39)-Al(1)-N(2) 90.22(14), $\mathrm{N}(1)-\mathrm{Al}(1)-\mathrm{N}(2) 75.91(12)$. 
Table 1 The ROP of $\varepsilon-C L$ catalyzed by complexes $2 a-2 f^{a}$

\begin{tabular}{|c|c|c|c|c|c|c|c|c|}
\hline Entry & Cat. & {$[\text { Cat. }]_{0}:[\mathrm{BnOH}]_{0}:[\mathrm{CL}]_{0}$} & $T\left({ }^{\circ} \mathrm{C}\right)$ & Time (h) & Conv. $^{b}(\%)$ & $M_{\mathrm{n}, \mathrm{calc}}{ }^{c}\left(\mathrm{~kg} \mathrm{\textrm {mol } ^ { - 1 } )}\right.$ & $M_{\mathrm{n}, \mathrm{GPC}}{ }^{d}\left(\mathrm{~kg} \mathrm{~mol}^{-1}\right)$ & $D^{e}$ \\
\hline 1 & $2 a$ & $1: 1: 100$ & 50 & 5 & 48.1 & 5.6 & 5.2 & 1.14 \\
\hline 2 & $2 b$ & $1: 1: 100$ & 70 & 0.5 & 99 & 11.4 & 11.0 & 1.31 \\
\hline 4 & $2 \mathbf{b}$ & $1: 1: 100$ & 25 & 1.5 & 89.3 & 10.3 & 8.6 & 1.08 \\
\hline 5 & $2 c$ & $1: 1: 100$ & 50 & 2 & 99 & 11.4 & 9.6 & 1.19 \\
\hline 6 & $2 d$ & $1: 1: 100$ & 50 & 8 & 93.2 & 10.7 & 6.1 & 1.13 \\
\hline $9^{f}$ & $2 f$ & $1: 0: 100$ & 25 & 1.5 & 99 & 11.4 & 8.6 & 1.12 \\
\hline
\end{tabular}

${ }^{a}$ Unless otherwise specified, the polymerization reactions were carried out in toluene, [Cat.] $=0.01 \mathrm{M} .{ }^{b}$ Measured by ${ }^{1} \mathrm{H}$ NMR spectra. ${ }^{c}$ Calculated from the molecular weight of $\varepsilon$-CL times the conversion of monomer and the ratio of $[\mathrm{CL}]_{0} /[\mathrm{BnOH}]_{\mathrm{o}}$ plus the molecular weight of BnOH. ${ }^{d} M_{\mathrm{n}}$ was obtained from GPC which was timed $0.56 .{ }^{14}{ }^{e} D$ was obtained from GPC analyses. ${ }^{f} M_{\mathrm{n} \text {,calc }}$ was calculated from the molecular weight of $\varepsilon$-CL times the conversion of monomer and the ratio of $[\mathrm{CL}]_{0} /[\mathrm{Cat}]_{0}$ plus the molecular weight of $\mathrm{BnOH}$.

Complex 2f also exhibits higher activity than aluminum bipyridine phenolate complex $\left[\mathrm{AlMe}_{2}\left(\mathrm{BpyPh}^{2,4-\mathrm{Bu}^{t}}\right)\right]$ reported in literature. ${ }^{7 k}$ From above activity order of $\mathbf{2 a - 2 f}$ it can be seen that bulky ortho-position substituents on the aromatic rings of phenoxy groups benefit increase of the catalytic activity of the complexes. 2-Position substituent on the phenanthroline ring makes against catalysis of the complex (Table 1, entry 6). The GPC molecular weights of the polymers match the calculated values very well when complexes $\mathbf{2 a - 2 c}$ were employed as the catalysts (Table 1, entries 1-5). However, the GPC molecular weights of the polymers are lower than the calculated values when complexes $\mathbf{2 d}$ and $\mathbf{2 e}$ were employed as the catalysts (Table 1, entries 6-8). In most cases, the polydispersities are narrow. However, the polydispersities was broadened with increase of polymerization temperatures (Table 1, entries 2-4, 7 and 8).

Kinetic study of $\varepsilon$-CL polymerization catalyzed by complex $\mathbf{2 f}$ was performed. Plots of $\ln \left([\mathrm{CL}]_{\mathrm{o}} /[\mathrm{CL}]\right)$ versus time revealed a linear relationship (Fig. 2), which indicates that the polymerization proceeds with first-order dependence on monomer concentration. This implies that the polymerization catalyzed by $2 \mathbf{f}$ is well controlled. The linear relationship of molecular

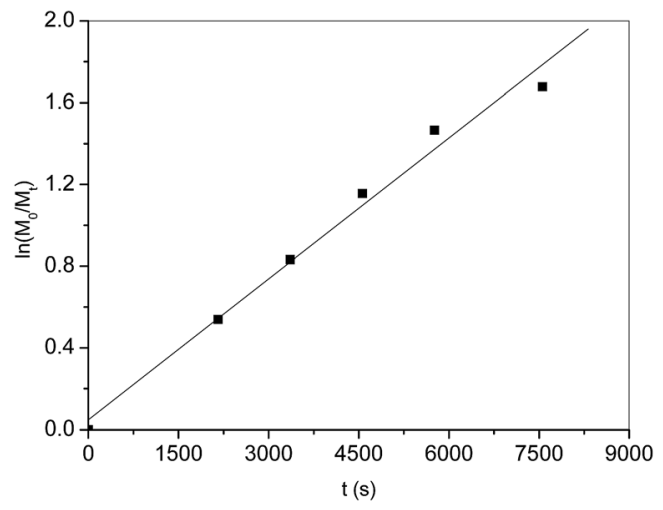

Fig. 2 Plot of $\ln \left([\mathrm{CL}]_{0} /[\mathrm{CL}]_{t}\right)$ versus time for the polymerization of $\varepsilon-\mathrm{CL}$ catalyzed by $2 \mathrm{f}$. Conditions: [Cat. $]_{0}:[\mathrm{BnOH}]_{0}:[\mathrm{CL}]_{0}=1: 0: 200$; [Cat.] $=0.01 \mathrm{M}$; solvent: toluene; temperature: $25^{\circ} \mathrm{C}$. weights of the polymers versus $\varepsilon$-CL conversion along with narrow PDI is another characteristic of living polymerization (Fig. 3). The corresponding SEC traces (Fig. 4) of the obtained polymers showed monomodal peaks with narrow PDI (1.071.08). The end group analysis of the PCL proved that the polymer was capped with a benzoxy group $\left(\mathrm{H}_{\mathrm{b}}\right)$ and a hydroxymethyl group $\left(\mathrm{H}_{\mathrm{g}}\right)$ (Fig. 5). All these facts imply that the polymerization initiated through insertion of $\varepsilon$-CL into an $\mathrm{Al}-\mathrm{OCH}_{2} \mathrm{Ph}$ bond followed by ring opening via acyl-oxygen cleavage.

\section{The ring-opening polymerization of rac-lactide}

Catalysis of complexes $2 \mathbf{a}-2 \mathrm{f}$ toward the ROP of rac-LA was evaluated, and the results showed that each of these complexes can catalyze the polymerization of rac-LA at elevated temperature (Table 2). Both $\mathbf{2 a}$ and $\mathbf{2 b}$ exhibited close activity in catalyzing polymerization of 100 equiv. of $\mathrm{rac}$-LA in toluene at $70{ }^{\circ} \mathrm{C}$ in the presence of $\mathrm{BnOH}$, leading to higher than $97 \%$ monomer conversion in $24 \mathrm{~h}$ (Table 2, entries 1 and 2). Complexes $2 \mathrm{c}$ and $2 d$ revealed much lower catalytic activity than $\mathbf{2 a}$ and $\mathbf{2 b}$ under the same conditions. $89.9 \%$ conversion of 100 equiv. of rac-LA was achieved in $72 \mathrm{~h}$ when $2 \mathrm{c} / \mathrm{BnOH}$ was employed as catalyst

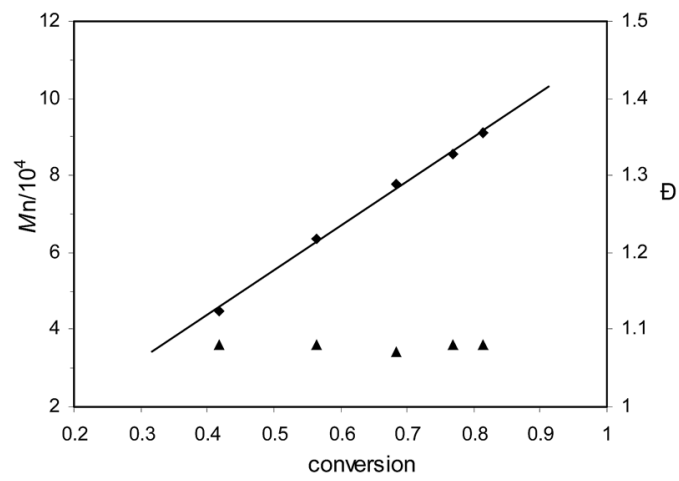

Fig. 3 Plots of PCL $M_{\mathrm{n}}$ ( $\bullet$, obtained from GPC analysis) and dispersity $\left(\boldsymbol{\Delta}: M_{\mathrm{w}} / M_{\mathrm{n}}\right.$ ) as a function of $\varepsilon-C L$ conversion using complex $2 \mathrm{f}$ as the catalyst. Conditions: $[2 \mathrm{f}]_{0}:[\mathrm{BnOH}]_{0}:[\mathrm{CL}]_{0}=1: 0: 200 ;[2 \mathrm{f}]_{0}=$ $0.01 \mathrm{M}$; solvent: toluene; temperature: $25^{\circ} \mathrm{C}$. 
and $60.9 \%$ of 100 equiv. of the monomer was concerted in $72 \mathrm{~h}$ when $2 \mathbf{d} / \mathrm{BnOH}$ was employed as catalyst (Table 2 , entries 3 and 4). Complex $2 \mathbf{e}$ showed a little lower activity than $\mathbf{2 a}$ and $\mathbf{2 b}$ (Table 2 , entry 5 ). The approximate activity order is $\mathbf{2 a} \approx \mathbf{2 b}>\mathbf{2 e}$

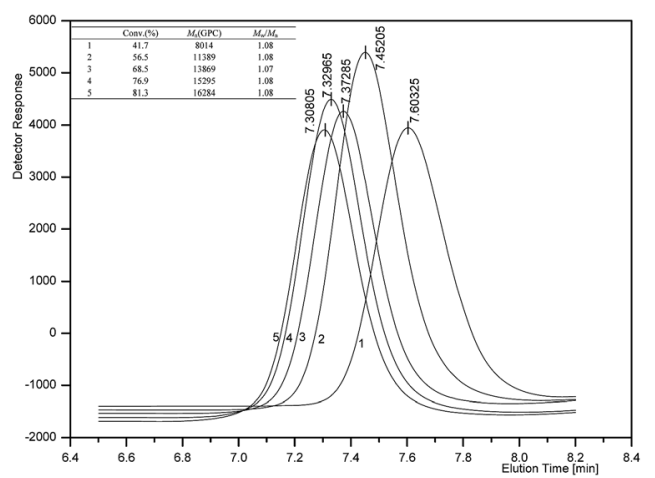

Fig. 4 The GPC curves of PCL depending different conversion catalyzed by $2 f$. Conditions: [Cat. $]_{0}:[\mathrm{BnOH}]_{0}:[\mathrm{CL}]_{0}=1: 0: 200 ;[$ Cat. $]=$ $0.01 \mathrm{M}$; solvent: toluene; temperature: $25^{\circ} \mathrm{C}$.

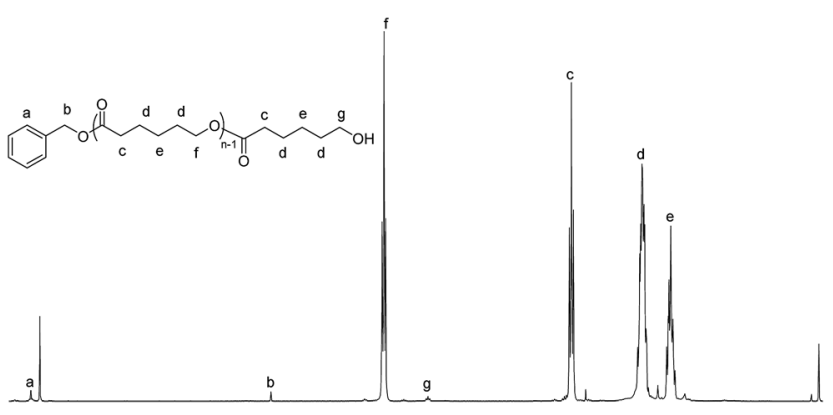

Fig. $5{ }^{1} \mathrm{H}$ NMR spectrum of PCL initiated by $2 \mathrm{~b} / \mathrm{BnOH}$ (Table 1 , entry 3).
$>2 \mathbf{c}>\mathbf{2 d}$. This activity order is different from that in catalyzing $\varepsilon$-CL polymerization. A bulky ortho-position substituent on the aromatic ring of phenoxy group is no longer necessary to increase the catalytic activity, and even unfavorable. However, the 2-position substituent on the phenanthroline ring is still unfavored as that shown in catalyzing $\varepsilon$-CL polymerization. Catalysis of $2 \mathbf{f}$ did not require presence of extra $\mathrm{BnOH}$. Its catalytic activity was close to that of $\mathbf{2 b}$ under comparable conditions. It also drove polymerization of 200 equiv. of rac-LA in good activity, $88.5 \%$ monomer conversion being achieved in $25 \mathrm{~h}$ (Table 2, entries 7 and 8). At lower temperature than $70{ }^{\circ} \mathrm{C}$, the catalytic activity of the complexes was markedly reduced. For example, $2 \mathrm{e} / \mathrm{BnOH}$ led to only $13.5 \%$ conversion of 100 equiv. of $\mathrm{rac}$-LA at $50{ }^{\circ} \mathrm{C}$ in $96 \mathrm{~h}$ (Table 2, entry 6); 2 f drove $97.1 \%$ conversion of 100 equiv. of rac-LA at $50{ }^{\circ} \mathrm{C}$ in $72 \mathrm{~h}$ (Table 2 , entry 9). Compared with aluminum bipyridine phenolate complexes, complexes $\mathbf{2 a}, \mathbf{2 b}$ and $\mathbf{2 f}$ exhibit slightly higher activity than

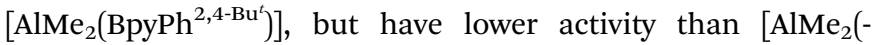
$\left.\left.\mathrm{BpyPh}^{4-\mathrm{Bu}^{t}}\right)\right]$ and $\left[\mathrm{AlMe}_{2}\left(\mathrm{BpyPh}^{2,4-\mathrm{Me}}\right)\right]{ }^{7 k}$ The GPC analysis revealed that molecular weight of the polymer catalyzed by $\mathbf{2 a} /$ $\mathrm{BnOH}$ matched the calculated value very well, but the PDI value is relatively wide (Table 2 , entry 1 ). The GPC molecular weights of the polymers catalyzed by $\mathbf{2 b}-\mathbf{2 e} / \mathrm{BnOH}$ and $2 \mathbf{f}$ were lower than the calculated values (Table 2, entries 2-9). A plausible reason could be the presence of side reactions such as transesterification and chain transfer in the process of polymerization. Catalysis of $\mathbf{2 b}$ was further evaluated with different $\mathrm{BnOH}$ or monomer loadings. The polymerization rate is almost same in the presence of 2 equiv. of $\mathrm{BnOH}$ using $\mathbf{2} \mathbf{b}$ as catalyst (Table 2, entry 10). In the absence of benzyl alcohol the reaction catalyzed by 2 b resulted in very viscous species at $70{ }^{\circ} \mathrm{C}$ in $14 \mathrm{~h}$. The ${ }^{1} \mathrm{H}$ NMR analysis indicated $84.2 \%$ monomer conversion and the GPC determination showed higher molecular weight of the final polymer than the expected value (Table 2, entry 11). This is

Table 2 The ROP of rac-lactide catalyzed by complexes $2 \mathrm{a}-2 \mathrm{f}^{a}$

\begin{tabular}{|c|c|c|c|c|c|c|c|c|}
\hline Entry & Cat. & {$[\text { Cat. }]_{0}:[\mathrm{BnOH}]_{0}:[\mathrm{LA}]_{0}$} & Time (h) & Conv. $^{b}(\%)$ & $M_{\mathrm{n}, \text { calc }^{c}}\left(\mathrm{~kg} \mathrm{\textrm {mol } ^ { - 1 } )}\right.$ & $M_{\mathrm{n}, \mathrm{GPC}}{ }^{d}\left(\mathrm{~kg} \mathrm{\textrm {mol } ^ { - 1 }}\right)$ & $D^{e}$ & $P_{\mathrm{m}}^{f}$ \\
\hline 1 & $2 a$ & $1: 1: 100$ & 24 & 97.4 & 14.1 & 13.6 & 1.46 & 0.48 \\
\hline 2 & $2 \mathbf{b}$ & $1: 1: 100$ & 24 & 97.1 & 14.1 & 7.6 & 1.19 & 0.74 \\
\hline 4 & $2 d$ & $1: 1: 100$ & 72 & 60.9 & 8.9 & 6.2 & 1.06 & 0.47 \\
\hline 5 & $2 e$ & $1: 1: 100$ & 24 & 90 & 13.1 & 6.9 & 1.10 & 0.76 \\
\hline $6^{g}$ & $2 \mathrm{e}$ & $1: 1: 100$ & 96 & 13.5 & & & & \\
\hline $9^{g}$ & $2 f$ & $1: 0: 100$ & 72 & 97.1 & $14.1^{h}$ & 7.2 & 1.11 & 0.78 \\
\hline 10 & $2 \mathbf{b}$ & $1: 2: 100$ & 24 & 96.2 & 7.0 & 4.7 & 1.17 & 0.74 \\
\hline 11 & $2 b$ & $1: 0: 100$ & 14 & 84.2 & & 20.9 & 1.24 & 0.75 \\
\hline 12 & $2 \mathbf{b}$ & $1: 1: 50$ & 23 & 93.8 & 6.9 & 4.4 & 1.15 & 0.72 \\
\hline 13 & $2 \mathbf{b}$ & $1: 1: 150$ & 24 & 94.9 & 20.6 & 12.9 & 1.24 & 0.76 \\
\hline 14 & $2 \mathbf{b}$ & $1: 1: 200$ & 24 & 98.7 & 28.6 & 16.0 & 1.21 & 0.77 \\
\hline
\end{tabular}

${ }^{a}$ Unless otherwise specified, the polymerization reactions were carried out at $70{ }^{\circ} \mathrm{C}$ in toluene, [Cat.] $=0.01 \mathrm{M} .{ }^{b}$ Measured by ${ }^{1} \mathrm{H}$ NMR spectra. ${ }^{c}$ Calculated from the molecular weight of rac-LA times the conversion of monomer and the ratio of $[\mathrm{LA}]_{0} /[\mathrm{BnOH}]_{0}$ plus the molecular weight of BnOH. ${ }^{d} M_{\mathrm{n}}$ was obtained from GPC which was timed $0.58 .{ }^{14}{ }^{e} \mathrm{D}$ was obtained from GPC analyses. ${ }^{f} P_{\mathrm{m}}$ is the probability of $m e s o$ linkages between monomer units determined from the methine region of the homonuclear decoupled ${ }^{1} \mathrm{H}$ NMR spectroscopy at $25{ }^{\circ} \mathrm{C}$ in $\mathrm{CDCl}{ }_{3}(\mathrm{Fig}$. S2, ESI). ${ }^{g}$ The polymerization reactions were carried out at $50{ }^{\circ} \mathrm{C} .{ }^{h} M_{\mathrm{n} \text {,calc }}$ was calculated from the molecular weight of $r a c$-LA times the conversion of monomer and the ratio of $[\mathrm{LA}]_{0} /[\mathrm{Cat}]_{0}$ plus the molecular weight of $\mathrm{BnOH}$. 
probably caused by trace amount of water or other impurities in the reaction system. Higher or lower than 100 equiv. of rac-LA loadings gave high monomer conversion at $70{ }^{\circ} \mathrm{C}$ in $24 \mathrm{~h}$ when catalyzed by $2 \mathbf{b} / \mathrm{BnOH}$ (Table 2 , entries $12-14$ ). A linear relationship between the number average molecular weights and $\left([\mathrm{LA}]_{0}-[\mathrm{LA}]\right) /[\mathrm{BnOH}]_{0}$ is observed (Fig. 6). This fact, combined with the narrow PDI values, imply the "living" character of the polymerization process and the possibility of the presence of multiple active species at high temperature, such as LAl(Et)OBn and $\mathrm{LAl}(\mathrm{OBn})_{2}$. Meanwhile, side reactions such as transesterification and chain transfer are also present from the MALDI-TOF MS of PLA (Fig. S1, ESI $\dagger$ ).

Homonuclear decoupled ${ }^{1} \mathrm{H}$ NMR spectra in the methine regions of the PLA showed that isotactic enriched PLA were obtained when complexes $2 \mathbf{b}, 2 \mathbf{c}, 2 \mathbf{e}$ and $2 \mathbf{f}$ were employed as the catalysts. The $P_{\mathrm{m}}$ value range from 0.62 to 0.78 . Complex $2 \mathrm{c}$ led to lower iso-selectivity and complexes $\mathbf{2 b}$ and $\mathbf{2 f}$ showed higher iso-selectivity. The iso-selectivity could be further enhanced by lowering the reaction temperature (Table 2, entry 9). Complexes $2 \mathbf{a}$ and $\mathbf{2 d}$ exhibited poor selectivity. They showed slightly heterotactic bias. These results proved that a bulky ortho-position substituent on the aromatic ring of phenoxy group is important to increase the selectivity, but too bulky substituent like cumyl group is disadvantageous to enhancement of the selectivity. That is to say, the steric hindrance of the substituent is too large or too small to be disadvantageous for the selectivity of the polymerization. This is inconsistent with previous studies that the enhancement of stereoselectivity requires bulky substituent. ${ }^{15}$ The presence of 2-position substituent on the phenanthroline ring is also disadvantageous to improve the selectivity. In addition, the catalytic selectivity of complexes $\mathbf{2 b}$ and $\mathbf{2 f}$ is also higher than that of aluminum bipyridine phenolate complex $\left[\mathrm{AlMe}_{2}\left(\mathrm{BpyPh}^{2,4-\mathrm{Bu}^{t}}\right)\right]$, which led to polymer with a $P_{\mathrm{m}}$ value of 0.70 at $70{ }^{\circ} \mathrm{C}$.

In order to better understand the polymerization process, the kinetics of rac-LA polymerization with complex $2 \mathbf{f}$ as the catalyst was studied. The plots of $\ln \left([\mathrm{LA}]_{0} /[\mathrm{LA}]_{t}\right)$ versus reaction time at different catalyst concentrations are shown in Fig. 7. The plots revealed linear relationship in each case, indicating the



Fig. 6 Plots of $M_{\mathrm{n}}(\bullet$, obtained from GPC analysis) and dispersity ( $\boldsymbol{\Delta}$ $\left.M_{w} / M_{n}\right)$ as a function of $\left.\left([L A]_{0}-[L A]\right) / B n O H\right]$ for the polymerization of rac-LA catalyzed by $2 \mathrm{~b} / \mathrm{BnOH}$ at $70{ }^{\circ} \mathrm{C}$. Conditions: [Cat.] $]_{0}=0.01 \mathrm{M}$; solvent: toluene.

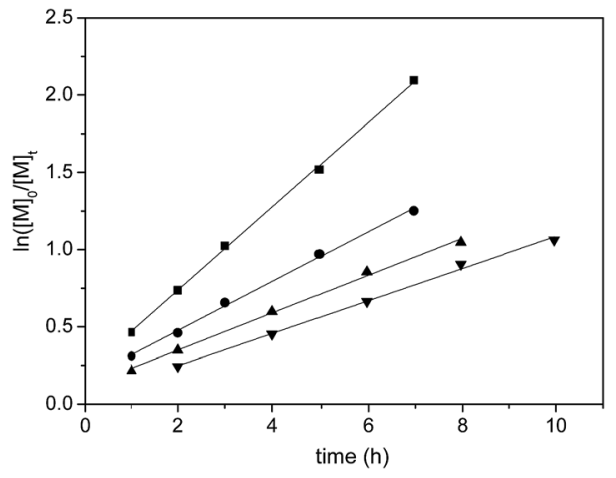

Fig. 7 Plot of $\ln \left([\mathrm{LA}]_{0} /[\mathrm{LA}]_{t}\right)$ versus time for the polymerization of rac$\mathrm{LA}$ catalyzed by $2 \mathrm{f}$ in toluene at $70{ }^{\circ} \mathrm{C}$, $[\mathrm{LA}]_{0}=0.5 \mathrm{M}$. (ם) $[\mathrm{LA}]_{0} /[\mathrm{Al}]_{0}=$ $20, K_{\mathrm{app}}=0.26936 \pm 0.0041 \mathrm{~h}^{-1} ;(\mathbf{O})[\mathrm{LA}]_{0} /[\mathrm{Al}]_{0}=30, K_{\mathrm{app}}=0.15847$ $\pm 0.00445 \mathrm{~h}^{-1} ;(\mathbf{\Delta})[\mathrm{LA}]_{0} /[\mathrm{Al}]_{0}=40, K_{\mathrm{app}}=0.11997 \pm 0.00376 \mathrm{~h}^{-1} ;(\boldsymbol{\nabla})$ $[\mathrm{LA}]_{0} /[\mathrm{Al}]_{0}=60, K_{\mathrm{app}}=0.10436 \pm 0.0034 \mathrm{~h}^{-1}$.

first order dependence of the polymerization on monomer concentration. The linear increase of $K_{\text {app }}$ with complex $2 \mathbf{f}$ concentration (Fig. 8) also indicates the order to be first-order. Therefore, the overall rate law in the form of $-\mathrm{d}[\mathrm{LA}] / \mathrm{d} t=$ $k_{\mathrm{p}}[\mathrm{LA}][\mathbf{2 f}]\left(k_{\mathrm{p}}=10.3 \mathrm{dm}^{3} \mathrm{~mol}^{-1} \mathrm{~h}^{-1}\right)$ was established. That is, the rate determining step involves one metal center and one monomer molecule stoichiometrically.

\section{The ring-opening polymerization of $\mathrm{rac}$ - $\beta$-butyrolactone}

Complexes $\mathbf{2 a - 2 d}$ and $\mathbf{2 f}$ were also assessed in the ring opening polymerization of $r a c-\beta$-BL. Polymerizations were carried out in toluene solution at $70{ }^{\circ} \mathrm{C}$ (Table 3). Both $2 \mathbf{b} / \mathrm{BnOH}$ and $2 \mathrm{f}$ showed good catalytic activity towards the ROP of $r a c-\beta-B L$. They drove polymerization of 100 equiv. of monomer in higher than 90\% conversions in $12 \mathrm{~h}$. Complex 2d exhibited the lowest activity in catalyzing the ROP. $2.9 \%$ conversion be achieved in 24 at the same monomer loading and reaction temperature as above. The molecular weights determined by GPC are markedly lower than the calculated values. This is ascribed to the presence of transesterification and chain transfer side reactions, which is further confirmed by MALDI-TOF MS analysis of PHB

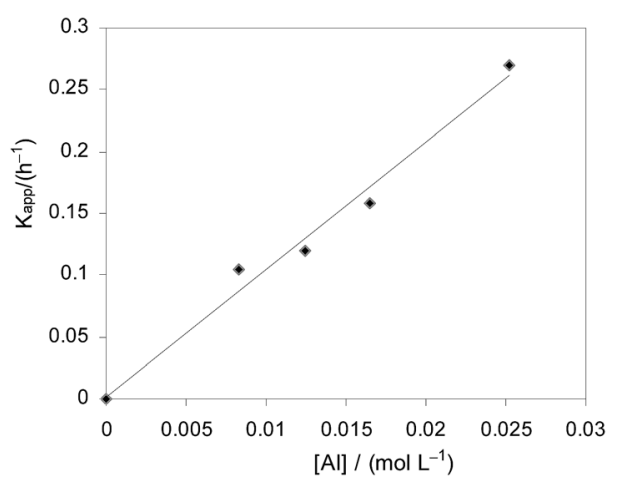

Fig. $8 K_{\text {app }}$ versus the concentration of $2 \mathrm{f}$ for the rac-LA polymerization at $70{ }^{\circ} \mathrm{C}$ in toluene $\left([\mathrm{LA}]_{0}=0.5 \mathrm{M}, k_{\mathrm{p}}=10.3 \mathrm{dm}^{3} \mathrm{~mol}^{-1} \mathrm{~h}^{-1}\right)$. 
Table 3 The ROP of $\beta$-butyrolactone catalyzed by complexes $2 \mathrm{a}-2 \mathrm{~d}$ and $2 \mathrm{f}^{a}$

\begin{tabular}{llllllr}
\hline Entry & Cat. & {$[\text { Cat. }]_{\mathrm{o}}:[\mathrm{BnOH}]_{\mathrm{o}}:[\beta-\mathrm{BL}]_{\mathrm{o}}$} & Time $(\mathrm{h})$ & Conv. $^{b}(\%)$ & $M_{\mathrm{n}, \mathrm{calc}}{ }^{c}(\mathrm{~kg} \mathrm{~mol}-1)$ & $M_{\mathrm{n}, \mathrm{GPC}}{ }^{d}(\mathrm{~kg}$ mol-1) \\
\hline 1 & 2a & $1: 1: 100$ & 12 & 37.9 & 3.4 & 2.2 \\
2 & 2b & $1: 1: 100$ & 5 & 41.9 & 3.7 & 1.2 \\
3 & 2b & $1: 1: 100$ & 12 & 94.4 & 8.3 & 3.5 \\
4 & 2c & $1: 1: 100$ & 24 & 72.1 & 6.3 & 2.0 \\
5 & 2d & $1: 1: 100$ & 24 & 2.9 & & 1.23 \\
6 & 2f & $1: 0: 100$ & 12 & 93.5 & $8.1^{f}$ & 1.14 \\
\end{tabular}

${ }^{a}$ Unless otherwise specified, the polymerization reactions were carried out at $70{ }^{\circ} \mathrm{C}$ in toluene, [Cat.] $=0.01 \mathrm{M} .{ }^{b}$ Measured by ${ }^{1} \mathrm{H}$ NMR spectra. ${ }^{c}$ Calculated from the molecular weight of rac-BL times the conversion of monomer and the ratio of $[\mathrm{BL}]_{\mathrm{o}} /[\mathrm{BnOH}]_{\mathrm{o}}$ plus the molecular weight of BnOH. ${ }^{d} M_{\mathrm{n}}$ was obtained from GPC which was timed $0.54 .{ }^{14} e \mathrm{D}$ was obtained from GPC analysis. ${ }^{f} M_{\mathrm{n}, \text { calc }}$ was calculated from the molecular weight of rac-BL times the conversion of monomer and the ratio of $[\mathrm{BL}]_{0} /[\mathrm{Cat}]_{0}$ plus the molecular weight of $\mathrm{BnOH}$.

(Fig. S3, ESI $\dagger$ ). It seems that the controllability showed by these complexes is lower than those found in the ROP of $\varepsilon$-CL and racLA. The polymer was atactic, as determined by the ${ }^{13} \mathrm{C}$ NMR analysis in the carbonyl and methylene regions (Fig. S4, ESI $\dagger$ ).

\section{Block copolymerization}

The synthesis of block copolymers was attempted by using catalyst $2 \mathrm{f}$ in toluene at different temperature (Table 4). For instance, the polymerization of 100 equiv. of $\varepsilon$-CL in toluene catalyzed by $2 \mathrm{f}$ at $25{ }^{\circ} \mathrm{C}$ went to completion in 1.5 hour. Then 100 equiv. of rac-LA were added to the reaction system and the reaction was run for further 24 hours at $70{ }^{\circ} \mathrm{C}$. ${ }^{1} \mathrm{H}$ NMR spectrum of the resulting mixture showed $\varepsilon$-CL and rac-LA were almost completely converted (Table 4 , entry 2 ). The sequential addition of the two monomers led to the achievement of a PCL$b$-PLA copolymer, which represents an experimental evidence of the living behavior of the polymerization promoted by this class of initiators. Other block copolymers can be synthesized in a similar manner (Fig. S5 and S6, ESI $\dagger$ ). In order to obtain the PHB- $b$-PLA copolymer, rac-LA had to be added to living PHB chains. The opposite sequence of monomers addition led mainly to PLA and a low amount of the block copolymer (Table 4 , entry 3). The importance of the order of the monomer addition in the block copolymerization was previously underlined in literature. ${ }^{16}$

In order to confirm formation of the copolymers, we monitored the polymerization process of $\varepsilon$-CL and $r a c$-LA catalyzed by 2f and charactered the polymers. When 100 equiv. of $\varepsilon$-CL monomer conversion approached to $99 \%$, a $1 / 8$ volume of sample was taken from the polymerization system for testing and showed its GPC $M_{\mathrm{n}}=11$ 174. Then 100 equiv. of rac-LA was added into the reaction system to generate the block copolymer PCL- $b$-PLA with GPC $M_{\mathrm{n}}=17187$ at 84.7\% rac-LA conversion (Fig. S7, ESI $\dagger$ ). ${ }^{1} \mathrm{H}$ NMR and ${ }^{13} \mathrm{C}$ NMR spectra of the PCL- $b$-PLA displayed all the characteristic signals, including the main bodies of the two blocks, BnO end and the monomer ends (Fig. 9 and 10). The ${ }^{13} \mathrm{C}$ NMR spectra show the connecting portions of diblock copolymers of PCL- $b$-PLA, which proved the formation of block copolymers. ${ }^{17}$ The 2D DOSY NMR spectrum of the copolymer provided further evidence for the copolymerization (Fig. S8, ESI $\dagger$ ). The spectrum showed that the multiplets of the poly( $\varepsilon$-caprolactone) block (centered at 4.05, 2.30 and 1.65 $\mathrm{ppm}$ ) and the multiplets of the poly(rac-lactide) block (centered at 5.15 and $1.57 \mathrm{ppm}$ ) lied at the same diffusion coefficient, and therefore belonged to the same polymeric chains. ${ }^{\mathbf{1 6 a , 1 8}}$ The ${ }^{1} \mathrm{H}$ NMR spectrum of the polymer (Fig. 9) indicated polymer chains

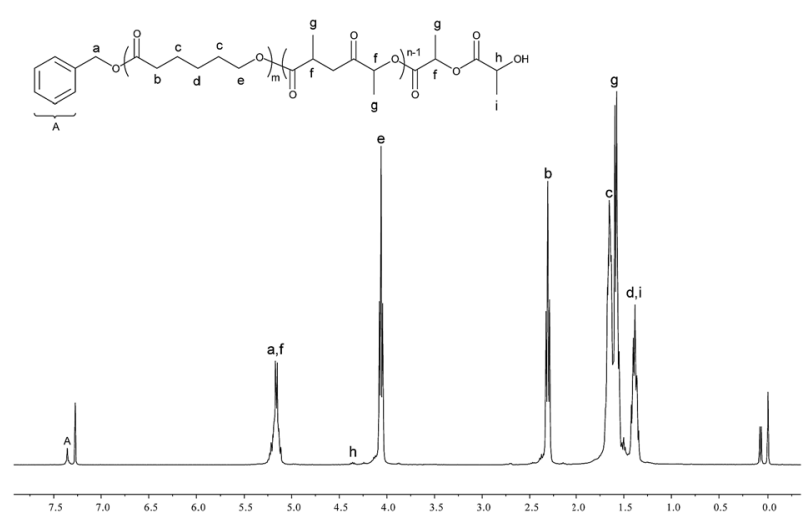

Fig. $9{ }^{1} \mathrm{H}$ NMR spectrum $\left(\mathrm{CDCl}_{3}, 400 \mathrm{MHz}, 25^{\circ} \mathrm{C}\right)$ of the PCL- $b$-PLA copolymer.

Table 4 Formation of block copolymer catalyzed by complex $2 \mathrm{f}^{a}$

\begin{tabular}{|c|c|c|c|c|c|c|c|}
\hline Entry & {$[\text { Cat. }]_{0}:\left[\mathrm{M}_{1}\right]_{0}:\left[\mathrm{M}_{2}\right]_{0}$} & Time (h) & $\mathrm{T}\left({ }^{\circ} \mathrm{C}\right)$ & Conv. ${ }^{b}\left(\mathrm{M}_{1}\right) \%$ & Conv. ${ }^{b}\left(\mathrm{M}_{2}\right) \%$ & $M_{\mathrm{n}, \mathrm{GPC}}{ }^{c}\left(\mathrm{~kg} \mathrm{~mol}^{-1}\right)$ & $D^{c}$ \\
\hline 1 & $2 f: C L: B L$ & $1.5+12$ & $25+70$ & 99 & 82 & 15.0 & 1.24 \\
\hline 2 & $2 f: C L: L A$ & $1.5+24$ & $25+70$ & 99 & 99 & 21.0 & 1.16 \\
\hline 4 & $2 f:$ BL : LA & $12+24$ & 70 & 98 & 84 & & \\
\hline
\end{tabular}

${ }^{a}$ The polymerization reactions were carried out in toluene, [Cat.] $=0.01 \mathrm{M}$. [Cat. $]_{0}:\left[\mathrm{M}_{1}\right]_{0}:\left[\mathrm{M}_{2}\right]_{0}=1: 100: 100 .{ }^{b}$ Measured by ${ }^{1} \mathrm{H}$ NMR spectra.

${ }^{c} M_{\mathrm{n}}$ and $D$ of copolymer was obtained from GPC analyses, GPC $M_{\mathrm{n}}$ without correction. 


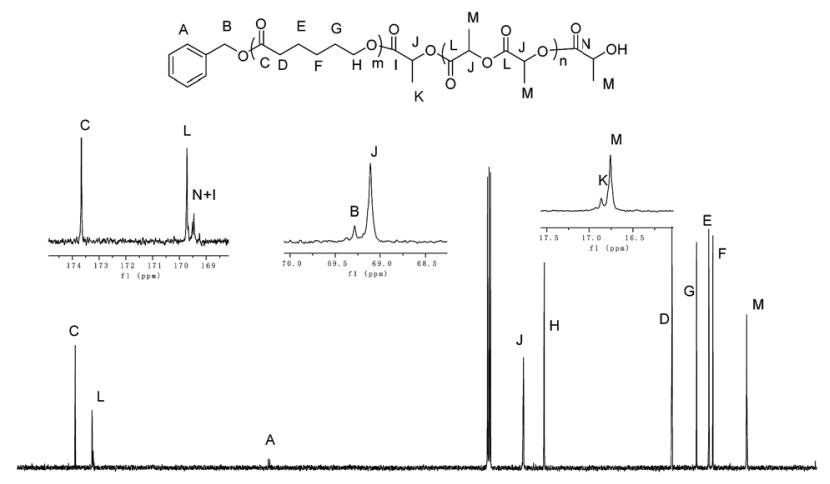

Fig. $10{ }^{13} \mathrm{C}$ NMR spectrum $\left(\mathrm{CDCl}_{3}, 101 \mathrm{MHz}, 25^{\circ} \mathrm{C}\right)$ of the PCL-b-PLA copolymer.

end-capped with a benzoxy group and a hydroxyl group. End group analysis of PCL- $b$-PHB copolymer by ${ }^{1} \mathrm{H}$ NMR spectroscopy also showed the polymer chains end-capped with a benzoxy group and a hydroxyl group (Fig. S5, ESI †े).

\section{Conclusions}

We have synthesized and characterized a series of aluminum complexes supported by 2-(1,10-phenanthrolin-2-yl)phenolate ligands. In the presence of $\mathrm{BnOH}$, the complexes efficiently catalyzed the ROP of $\varepsilon$-CL, $r a c$-LA and rac- $\beta$-BL. The catalytic activity of the complexes is affected by the substituents on the ligands. In each case the 2-position substituent on the phenanthroline ring of the ligand is unfavored. The pluses and minuses of the bulky ortho-position substituent on the aromatic ring of phenoxy group depend on reaction substrates that they catalyzed, but too bulky substituent is often unfavorable. The polymerization reaction led to PCL with good molecular weight control and narrow molecular weight distribution. Isotactic enriched PLA were obtained when $\mathbf{2 b}, \mathbf{2 c}, \mathbf{2 e}$ and $\mathbf{2 f}$ were used as the catalysts, while atactic poly(hydroxybutyrate) was got no matter which complex was employed. Kinetic analysis using $\mathbf{2 f}$ as the catalyst revealed that the polymerization of $\varepsilon$-CL was firstorder dependence on monomer concentration, and the polymerization of rac-LA proceeded with first-order dependence on both monomer and catalyst concentration. The block polymerization were also performed utilizing the "living" character of the aluminum catalysts, forming block copolymers including PCL- $b$-PHB, PCL- $b$-PLA, and PHB- $b$-PLA.

\section{Experimental}

All air or moisture sensitive manipulations were performed under dry $\mathrm{N}_{2}$ using standard Schlenk techniques. Solvents were distilled under $\mathrm{N}_{2}$ over sodium/benzophenone ( $n$-hexane and diethyl ether) or sodium (toluene) and degassed prior to use. $\mathrm{AlEt}_{3}$ was purchased from Acros Organics and used as received. $\mathrm{C}_{6} \mathrm{D}_{6}$ and $\mathrm{CDCl}_{3}$ were purchased from Cambridge Isotope Laboratories, Inc., and were degassed and stored over $\mathrm{Na} / \mathrm{K}$ alloy $\left(\mathrm{C}_{6} \mathrm{D}_{6}\right)$ or $4 \AA$ molecular sieves $\left(\mathrm{CDCl}_{3}\right)$. $\varepsilon$-CL and rac- $\beta$-BL were stirred over $\mathrm{CaH}_{2}$ for $24 \mathrm{~h}$ and distilled under vacuum. racLA was recrystallized three times from toluene prior to use. $o$ Bromophenols and 2-butyl-1,10-phenanthroline were prepared according to the reported methods. ${ }^{19}$ Other chemicals and solvents were purchased from commercial venders. NMR spectra were recorded on a Bruker av400 spectrometer at ambient temperature. The chemical shifts of ${ }^{1} \mathrm{H}$ and ${ }^{13} \mathrm{C}$ NMR spectra were referenced to TMS or internal solvent resonances. Elemental analyses were performed on an Elementar Vario EL cube analyzer. Gel permeation chromatography (GPC) measurements were performed on a Waters 150C instrument equipped with UltraStyragel columns $(103,104$, and $105 \AA)$ and a 410 refractive index detector, using monodispersed polystyrene as the calibration standard. THF (HPLC grade) was used as an eluent at a flow rate of $1 \mathrm{~cm}^{3} \mathrm{~min}^{-1}$.

\section{Synthesis of 1a}

To a stirred solution of 2-bromo-4-(tert-butyl)phenol (1.37 g, 6.0 $\mathrm{mmol})$ in $\mathrm{Et}_{2} \mathrm{O}\left(20 \mathrm{~cm}^{3}\right), \mathrm{Bu}^{n} \mathrm{Li}(2.5 \mathrm{M}$ solution in hexane, 5.3 $\mathrm{cm}^{3}, 13.25 \mathrm{mmol}$ ) was added dropwise at $-78{ }^{\circ} \mathrm{C}$. After stirring for $2 \mathrm{~h}$ at room temperature, the resulting mixture was added dropwise to 1,10-phenanthroline $(0.90 \mathrm{~g}, 5.0 \mathrm{mmol})$ in toluene $\left(30 \mathrm{~cm}^{3}\right)$. The dark purple solution was stirred at the same temperature for additional $20 \mathrm{~h}$. The reaction mixture was quenched with water $\left(20 \mathrm{~cm}^{3}\right)$ and extracted with ethyl acetate. The combined organic layers were dried over $\mathrm{Na}_{2} \mathrm{SO}_{4}$ and then removed solvent by rotary evaporation. The residue was used for the next step without further purification. To a stirred solution of the crude product in ethyl acetate $\left(20 \mathrm{~cm}^{3}\right), \mathrm{MnO}_{2}(8.7 \mathrm{~g}, 100$ $\mathrm{mmol}$ ) was added at room temperature. The black suspension was stirred at $60{ }^{\circ} \mathrm{C}$ for $12 \mathrm{~h}$. The resulting mixture was dried over $\mathrm{MgSO}_{4}$ and filtered through a celite pad to remove $\mathrm{MnO}_{2}$. The organic layers were evaporated and purified by column chromatography (eluting with hexane/ethyl acetate $=2: 1$ ) to afford 1a as a yellow solid in overall $26.8 \%$ yield $(0.44 \mathrm{~g}, 1.34$ mmol). Anal. calcd for $\mathrm{C}_{22} \mathrm{H}_{20} \mathrm{~N}_{2} \mathrm{O} \cdot 0.1 \mathrm{C}_{4} \mathrm{H}_{8} \mathrm{O}_{2}: \mathrm{C}, 79.78 ; \mathrm{H}, 6.22$; $\mathrm{N}, 8.31 \%$. Found: C, $79.95 \mathrm{H}, 6.29$; N, 8.22\%. ${ }^{1} \mathrm{H}$ NMR $(400 \mathrm{MHz}$, $\left.\mathrm{CDCl}_{3}\right): \delta 16.13(\mathrm{~s}, 1 \mathrm{H}, \mathrm{OH}), 9.16(\mathrm{~d}, J=4.2 \mathrm{~Hz}, 1 \mathrm{H}, \mathrm{Ar}), 8.30(\mathrm{~d}, J$ $=8.7 \mathrm{~Hz}, 1 \mathrm{H}, \mathrm{Ar}), 8.24-8.17(\mathrm{~m}, 2 \mathrm{H}, \mathrm{Ar}), 7.96(\mathrm{~d}, J=2.2 \mathrm{~Hz}, 1 \mathrm{H}$, $\mathrm{Ar}), 7.73(\mathrm{~s}, 2 \mathrm{H}, \mathrm{Ar}), 7.60(\mathrm{dd}, J=8.0,4.3 \mathrm{~Hz}, 1 \mathrm{H}, \mathrm{Ar}), 7.45(\mathrm{dd}, J$ $=8.6,2.3 \mathrm{~Hz}, 1 \mathrm{H}, \mathrm{Ar}), 7.14(\mathrm{~d}, J=8.6 \mathrm{~Hz}, 1 \mathrm{H}, \mathrm{Ar}), 1.41(\mathrm{~s}, 9 \mathrm{H}$, $\left.\mathrm{Bu}^{t}\right) .{ }^{13} \mathrm{C}$ NMR $\left(101 \mathrm{MHz}, \mathrm{CDCl}_{3}\right): \delta$ 159.49, 157.70, 150.74, $144.80,142.87,140.80,137.25,135.86,129.70,128.98,126.39$, $126.31,125.75,123.41,122.68,118.83,118.36,117.93,34.33$, 31.74 .

\section{Synthesis of $\mathbf{1 b}$}

Compound $\mathbf{1 b}$ was synthesized using the same procedure as for 1a. Thus, 2-bromo-4,6-di-tert-butylphenol (1.42 g, $5 \mathrm{mmol})$ was treated successively with $\mathrm{Bu}^{n} \mathrm{Li}\left(4.4 \mathrm{~cm}^{3}, 2.5 \mathrm{M}\right.$ solution in hexane, $11 \mathrm{mmol}$ ) and 1,10-phenanthroline (0.90 g, $5.0 \mathrm{mmol})$. The resulting species was oxidized with $\mathrm{MnO}_{2}$ to afford, after purified by column chromatography (eluting with hexane/ethyl acetate $=5: 1), \mathbf{1 b}$ as an orange solid in overall $41.3 \%$ yield $(0.794 \mathrm{~g}, 2.06 \mathrm{mmol})$. Anal. calcd for $\mathrm{C}_{26} \mathrm{H}_{28} \mathrm{~N}_{2} \mathrm{O} \cdot 0.15 \mathrm{C}_{4} \mathrm{H}_{8} \mathrm{O}_{2}: \mathrm{C}$, 
80.33; H, 7.40; N, 7.04\%. Found: C, $80.40 \mathrm{H}, 7.57$; N, 7.02\%. ${ }^{1} \mathrm{H}$ NMR (400 MHz, $\left.\mathrm{CDCl}_{3}\right): \delta 16.11(\mathrm{~s}, 1 \mathrm{H}, \mathrm{OH}), 9.21(\mathrm{dd}, J=4.3$, $1.6 \mathrm{~Hz}, 1 \mathrm{H}, \mathrm{Ar}), 8.32-8.18$ (m, 3H, Ar), 7.85 (d,J=2.3 Hz, 1H, Ar), 7.74 (d, $J=2.4 \mathrm{~Hz}, 2 \mathrm{H}, \mathrm{Ar}$ ), 7.61 (dd, $J=8.1,4.3 \mathrm{~Hz}, 1 \mathrm{H}, \mathrm{Ar}), 7.49$ $(\mathrm{d}, J=2.1 \mathrm{~Hz}, 1 \mathrm{H}, \mathrm{Ar}), 1.60\left(\mathrm{~s}, 9 \mathrm{H}, \mathrm{Bu}^{t}\right), 1.41\left(\mathrm{~s}, 9 \mathrm{H}, \mathrm{Bu}^{t}\right) .{ }^{13} \mathrm{C}$ NMR (101 MHz, $\mathrm{CDCl}_{3}$ ): $\delta$ 158.82, 158.69, 150.77, 144.91, 142.77, 139.35, 138.22, 137.16, 135.98, 129.02, 127.03, 126.27, $126.17,125.87,123.29$, 121.12, 119.39, 117.87, 35.63, 34.52, 31.81, 29.94 .

\section{Synthesis of 1c}

Compound 1c was synthesized using the same procedure as for 1a. Thus, 2-bromo-4,6-bis( $\alpha, \alpha$-dimethylbenzyl) phenol (2.45 g, 6 mmol) was treated successively with $\mathrm{Bu}^{n} \mathrm{Li}\left(5.3 \mathrm{~cm}^{3}, 13.25\right.$ $\mathrm{mmol})$ and 1,10-phenanthroline $(0.90 \mathrm{~g}, 5.0 \mathrm{mmol})$. The resulting species was oxidized with $\mathrm{MnO}_{2}$ to afford, after purified by column chromatography (eluting with hexane/ethyl acetate $=2: 1$ ), 1c as a light yellow solid in overall $10.3 \%$ yield ( $0.21 \mathrm{~g}, 0.52 \mathrm{mmol})$. Anal. calcd for $\mathrm{C}_{36} \mathrm{H}_{32} \mathrm{~N}_{2} \mathrm{O}: \mathrm{C}, 85.01 ; \mathrm{H}$, 6.34; N, 5.51\%. Found: C, 85.03 H, 6.48; N, 5.43. ${ }^{1} \mathrm{H}$ NMR (400 $\mathrm{MHz}_{\mathrm{CDCl}}$ ): $\delta 15.40(\mathrm{~s}, 1 \mathrm{H}, \mathrm{OH}), 9.01(\mathrm{~d}, J=3.0 \mathrm{~Hz}, 1 \mathrm{H}, \mathrm{Ar})$, $8.10(\mathrm{~d}, J=8.7 \mathrm{~Hz}, 1 \mathrm{H}, \mathrm{Ar}), 8.06$ (d, $J=7.9 \mathrm{~Hz}, 1 \mathrm{H}, \mathrm{Ar}), 7.97$ (d, $=8.7 \mathrm{~Hz}, 1 \mathrm{H}, \mathrm{Ar}), 7.73(\mathrm{~s}, 1 \mathrm{H}, \mathrm{Ar}), 7.57$ (s, 2H, Ar), $7.48(\mathrm{dd}, J=$ 7.9, $4.3 \mathrm{~Hz}, 1 \mathrm{H}, \mathrm{Ar}$ ), 7.40 (s, 1H, Ar), 7.38-7.29 (m, 6H, Ar), 7.29$7.19(\mathrm{~m}, 3 \mathrm{H}, \mathrm{Ar}), 7.12$ (t, J= 7.0 Hz, 1H, Ar), 1.83 (s, 6H, Me), 1.80 (s, 6H, Me). ${ }^{13} \mathrm{C}$ NMR (101 $\left.\mathrm{MHz}, \mathrm{CDCl}_{3}\right): \delta$ 158.27, 157.93, 151.35 , 151.26, 150.45, 144.53, 142.60, 138.89, 137.49, 137.10, $135.89,129.23,128.85,128.13,127.85,126.96,126.24,126.16$, $126.08,125.78,125.70,125.05,123.38,123.13,119.27,118.38$, $42.81,31.20,29.86$.

\section{Synthesis of $1 \mathrm{~d}$}

Compound 1d was synthesized using the same procedure as for 1a. Thus, 2-bromo-4,6-di-tert-butylphenol (1.59 g, $5.6 \mathrm{mmol}$ ) was treated successively with $\mathrm{Bu}^{n} \mathrm{Li}\left(4.9 \mathrm{~cm}^{3}, 12.32 \mathrm{mmol}\right)$ and 2butyl-1,10-phenanthroline (1.1 g, $4.6 \mathrm{mmol})$. The resulting species was oxidized with $\mathrm{MnO}_{2}$ to afford, after purified by column chromatography (eluting with hexane/ethyl acetate $=$ $2: 1)$ to afford $1 \mathrm{~d}$ as an orange solid in overall $42 \%$ yield ( $0.86 \mathrm{~g}$, $1.93 \mathrm{mmol}$ ). Anal. calcd for $\mathrm{C}_{30} \mathrm{H}_{36} \mathrm{~N}_{2} \mathrm{O} \cdot 0.06 \mathrm{C}_{4} \mathrm{H}_{8} \mathrm{O}_{2}: \mathrm{C}, 81.45 ; \mathrm{H}$, 8.25; N, 6.28\%. Found: C, $81.39 \mathrm{H}, 8.03$; N, 6.32. ${ }^{1} \mathrm{H}$ NMR $(400$ $\mathrm{MHz}, \mathrm{CDCl}_{3}$ ): $\delta 16.51$ (s, $\left.1 \mathrm{H}, \mathrm{OH}\right), 8.28(\mathrm{~d}, J=8.7 \mathrm{~Hz}, 1 \mathrm{H}, \mathrm{Ar})$, $8.22(\mathrm{~d}, J=8.8 \mathrm{~Hz}, 1 \mathrm{H}, \mathrm{Ar}), 8.10$ (d, $J=8.2 \mathrm{~Hz}, 1 \mathrm{H}, \mathrm{Ar}), 7.86$ (d, $J$ $=2.3 \mathrm{~Hz}, 1 \mathrm{H}, \mathrm{Ar}), 7.74-7.67$ (m, 2H, Ar), 7.50-7.45 (m, 2H, Ar), $3.17\left(\mathrm{t}, J=7.8 \mathrm{~Hz}, 2 \mathrm{H}, \mathrm{CH}_{2}\right), 2.24-2.15\left(\mathrm{~m}, 2 \mathrm{H}, \mathrm{CH}_{2}\right), 1.61-1.51$ $\left(\mathrm{m}, 2 \mathrm{H}, \mathrm{CH}_{2}\right), 1.60\left(\mathrm{~s}, 9 \mathrm{H}, \mathrm{Bu}^{t}\right), 1.41\left(\mathrm{~s}, 9 \mathrm{H}, \mathrm{Bu}^{t}\right), 1.08(\mathrm{t}, J=$ $7.4 \mathrm{~Hz}, 3 \mathrm{H}, \mathrm{Me}) .{ }^{13} \mathrm{C}$ NMR $\left(101 \mathrm{MHz}, \mathrm{CDCl}_{3}\right): \delta 163.26,159.07$, 158.48, 144.14, 142.50, 139.06, 138.30, 137.00, 135.87, 127.07, $126.83,126.19,125.93,124.68,123.67,120.86,118.81,117.73$, $38.74,35.67,34.52,31.83,30.41,29.86,22.90,14.31$.

\section{Synthesis of $2 \mathrm{a}$}

A solution of 1a $(0.328 \mathrm{~g}, 1.0 \mathrm{mmol})$ in toluene $\left(15 \mathrm{~cm}^{3}\right)$ was cooled to $0{ }^{\circ} \mathrm{C}$. $\operatorname{AlEt}_{3}\left(1.83 \mathrm{~cm}^{3}, 0.6 \mathrm{M}\right.$ solution in heptane, 1.1 $\mathrm{mmol}$ ) was added dropwise to the cooled solution. The color of the solution instantly changed from light yellow to deep red.
The resultant mixture was warmed to room temperature and stirred for $12 \mathrm{~h}$. The solution was filtered and the filtrate was concentrated to afford deep red crystalline solid of $2 \mathrm{a}(0.198 \mathrm{~g}$, $48 \%$ ). Anal. calcd for $\mathrm{C}_{26} \mathrm{H}_{29} \mathrm{AlN}_{2} \mathrm{O}$ : C, 75.70; $\mathrm{H}, 7.09 ; \mathrm{N}, 6.79 \%$. Found: C, $75.43 \mathrm{H}, 6.84 ; \mathrm{N}, 6.59 .{ }^{1} \mathrm{H}$ NMR (400 MHz, $\mathrm{C}_{6} \mathrm{D}_{6}$ ): $\delta 8.57(\mathrm{dd}, J=4.7,1.4 \mathrm{~Hz}, 1 \mathrm{H}, \mathrm{Ar}), 7.64(\mathrm{~d}, J=8.9 \mathrm{~Hz}, 1 \mathrm{H}, \mathrm{Ar})$, $7.60(\mathrm{~d}, J=2.4 \mathrm{~Hz}, 1 \mathrm{H}, \mathrm{Ar}), 7.48$ (d, $J=8.8 \mathrm{~Hz}, 1 \mathrm{H}, \mathrm{Ar}), 7.39$ (dd, $J$ $=8.8,2.5 \mathrm{~Hz}, 1 \mathrm{H}, \mathrm{Ar}), 7.35(\mathrm{~d}, J=8.8 \mathrm{~Hz}, 1 \mathrm{H}, \mathrm{Ar}), 7.30(\mathrm{dd}, J=$ 8.2, $1.3 \mathrm{~Hz}, 1 \mathrm{H}, \mathrm{Ar}$ ), 6.99-6.94 (m, 2H, Ar), 6.73 (dd, $J=8.1$, $4.7 \mathrm{~Hz}, 1 \mathrm{H}, \mathrm{Ar}), 1.54(\mathrm{t}, J=8.0 \mathrm{~Hz}, 6 \mathrm{H}, \mathrm{Me}), 1.32\left(\mathrm{~s}, 9 \mathrm{H}, \mathrm{Bu}^{t}\right)$, 0.75-0.64 (m, 2H, Al- $\left.\mathrm{CH}_{2}\right), 0.53-0.43\left(\mathrm{~m}, 2 \mathrm{H}, \mathrm{Al}-\mathrm{CH}_{2}\right) .{ }^{13} \mathrm{C} \mathrm{NMR}$ (101 MHz, $\left.\mathrm{C}_{6} \mathrm{D}_{6}\right): \delta 165.23,161.07,146.34,140.91,140.03$, 138.22, 138.12, 136.78, 132.71, 127.98, 126.14, 125.55, 124.56, $124.30,124.01,123.28,119.39,34.16,31.75,11.96,6.98$.

\section{Synthesis of $2 b$}

A solution of $\mathbf{1 b}(0.23 \mathrm{~g}, 0.60 \mathrm{mmol})$ in toluene $\left(15 \mathrm{~cm}^{3}\right)$ was cooled to $0{ }^{\circ} \mathrm{C}$. $\operatorname{AlEt}_{3}\left(1.1 \mathrm{~cm}^{3}, 0.6 \mathrm{M}\right.$ solution in heptane, 0.66 $\mathrm{mmol}$ ) was added to the cooled solution. The resultant mixture was warmed to room temperature and stirred for $12 \mathrm{~h}$. The solution was filtered and the filtrate was concentrated to afford deep red crystalline solid of $2 \mathbf{b}(0.28 \mathrm{~g}, 81 \%)$. Anal. calcd for $\mathrm{C}_{30} \mathrm{H}_{37} \mathrm{AlN}_{2} \mathrm{O}: \mathrm{C}, 76.89 ; \mathrm{H}, 7.96 ; \mathrm{N}, 5.98 \%$. Found: $\mathrm{C}, 76.78 \mathrm{H}$, 7.94; N, 6.08. ${ }^{1} \mathrm{H}$ NMR (400 MHz, $\left.\mathrm{C}_{6} \mathrm{D}_{6}\right): \delta 8.60(\mathrm{~d}, J=4.7 \mathrm{~Hz}, 1 \mathrm{H}$, $\mathrm{Ar}), 7.84(\mathrm{~d}, J=2.4 \mathrm{~Hz}, 1 \mathrm{H}, \mathrm{Ar}), 7.63-7.56(\mathrm{~m}, 1 \mathrm{H}, \mathrm{Ar}), 7.54(\mathrm{~s}, 1 \mathrm{H}$, Ar), 7.29 (d, $J=8.8 \mathrm{~Hz}, 2 \mathrm{H}, \mathrm{Ar}), 6.98-6.90$ (m, 2H, Ar), 6.76-6.69 (m, 1H, Ar), $1.99\left(\mathrm{~s}, 9 \mathrm{H}, \mathrm{Bu}^{t}\right), 1.43\left(\mathrm{~s}, 9 \mathrm{H}, \mathrm{Bu}^{t}\right), 1.39(\mathrm{t}, J=8.1 \mathrm{~Hz}$, 6H, Me), 0.78-0.67 (m, 2H, Al- $\mathrm{CH}_{2}$ ), 0.54-0.43 (m, 2H, Al- $\mathrm{CH}_{2}$ ). ${ }^{13} \mathrm{C}$ NMR (101 MHz, $\left.\mathrm{C}_{6} \mathrm{D}_{6}\right)$ : $\delta$ 164.31, 161.70, 146.49, 141.78, $140.67,140.23$, 137.84, 137.42, 136.70, 129.18, 127.91, 126.14, $125.31,124.60,124.14,123.92,123.16,119.88,36.18,34.49$, $31.92,30.40,11.82,6.97,6.52$.

\section{Synthesis of $2 \mathrm{c}$}

1c $(0.182 \mathrm{~g}, 0.36 \mathrm{mmol})$ was dissolved in toluene $\left(10 \mathrm{~cm}^{3}\right)$ and cooled to $0{ }^{\circ} \mathrm{C}$. To the solution was added $\mathrm{AlEt}_{3}\left(0.72 \mathrm{~cm}^{3}, 0.6 \mathrm{M}\right.$ solution in heptane, $0.43 \mathrm{mmol})$. The resultant mixture was warmed to room temperature and stirred overnight. The solution was filtered and the filtrate was concentrated to afford deep red crystalline solid of $2 \mathrm{c}(0.16 \mathrm{~g}, 76.4 \%)$. Anal. calcd for $\mathrm{C}_{40^{-}}$ $\mathrm{H}_{41} \mathrm{AlN}_{2} \mathrm{O} \cdot \mathrm{C}_{7} \mathrm{H}_{8}: \mathrm{C}, 82.42 ; \mathrm{H}, 7.21 ; \mathrm{N}, 4.09 \%$. Found: $\mathrm{C}, 82.25 \mathrm{H}$, 6.98; N, 4.25. ${ }^{1} \mathrm{H}$ NMR (400 MHz, $\left.\mathrm{C}_{6} \mathrm{D}_{6}\right): \delta 8.56(\mathrm{dd}, J=4.8$, $1.4 \mathrm{~Hz}, 1 \mathrm{H}, \mathrm{Ar}), 7.77$ (d, J=2.4 Hz, 1H, Ar), 7.72-7.67 (m, 2H, Ar), $7.50(\mathrm{~d}, J=2.4 \mathrm{~Hz}, 1 \mathrm{H}, \mathrm{Ar}), 7.49-7.42(\mathrm{~m}, 3 \mathrm{H}, \mathrm{Ar}), 7.36(\mathrm{t}, J=$ $7.8 \mathrm{~Hz}, 2 \mathrm{H}, \mathrm{Ar}$ ), 7.29-7.08 (m, 7H, Ar), 7.07-7.00 (m, 3H, Ar), 6.87 (s, 2H, Ar), 6.65 (dd, J=8.1, 4.8 Hz, 1H, Ar), 2.12 (s, 6H, Me), 2.11 (s, toluene), $1.78(\mathrm{~s}, 6 \mathrm{H}, \mathrm{Me}), 1.12(\mathrm{t}, J=8.1 \mathrm{~Hz}, 6 \mathrm{H}, \mathrm{Me}), 0.43-$ $0.33\left(\mathrm{~m}, 2 \mathrm{H}, \mathrm{CH}_{2}\right), 0.24-0.14\left(\mathrm{~m}, 2 \mathrm{H}, \mathrm{CH}_{2}\right) .{ }^{13} \mathrm{C}$ NMR $(101 \mathrm{MHz}$, $\left.\mathrm{C}_{6} \mathrm{D}_{6}\right): \delta 163.96,161.19,151.91,151.84,146.35,141.72,140.66$, 140.22 , 137.89, 137.58, 136.83, 136.59, 131.35, 129.33, 128.57, $128.45,128.19,127.94,127.37,126.62$, 126.02, 125.98, 125.70, $125.58,125.25,125.20,124.37,124.11,123.89,119.72,43.22$, $43.00,31.41,30.08,11.43,6.16$. 


\section{Synthesis of $2 d$}

A solution of $1 \mathrm{~d}(0.47 \mathrm{~g}, 1.07 \mathrm{mmol})$ in toluene $\left(15 \mathrm{~cm}^{3}\right)$ was cooled to $0{ }^{\circ} \mathrm{C}$. AlEt $3\left(2.0 \mathrm{~cm}^{3}, 0.6 \mathrm{M}\right.$ solution in heptane, 1.2 $\mathrm{mmol}$ ) was added to the cooled solution. The resultant mixture was warmed to room temperature and stirred overnight. The solution was filtered and the filtrate was concentrated to afford red crystalline solid of $2 \mathbf{d}(0.26 \mathrm{~g}, 46.3 \%)$. Anal. calcd for $\mathrm{C}_{34} \mathrm{H}_{45} \mathrm{AlN}_{2} \mathrm{O}$ : C, 77.83; H, 8.64; N, 5.34\%. Found: C, $77.77 \mathrm{H}$, 8.70; N, 5.21. ${ }^{1} \mathrm{H}$ NMR $\left(400 \mathrm{MHz}, \mathrm{C}_{6} \mathrm{D}_{6}\right): \delta 7.84(\mathrm{~d}, J=2.5 \mathrm{~Hz}, 1 \mathrm{H}$, $\mathrm{Ar}), 7.58(\mathrm{~d}, J=8.9 \mathrm{~Hz}, 1 \mathrm{H}, \mathrm{Ar}), 7.53(\mathrm{~d}, J=2.4 \mathrm{~Hz}, 1 \mathrm{H}, \mathrm{Ar}), 7.41$ (d, $J=8.4 \mathrm{~Hz}, 1 \mathrm{H}, \mathrm{Ar}), 7.33$ (d, $J=8.8 \mathrm{~Hz}, 1 \mathrm{H}, \mathrm{Ar}), 7.07$ (d, $J=$ $8.7 \mathrm{~Hz}, 1 \mathrm{H}, \mathrm{Ar}), 7.00(\mathrm{~d}, J=8.7 \mathrm{~Hz}, 1 \mathrm{H}, \mathrm{Ar}), 6.94(\mathrm{~d}, J=8.4 \mathrm{~Hz}$, $1 \mathrm{H}, \mathrm{Ar}), 3.35-3.27\left(\mathrm{~m}, 2 \mathrm{H}, \mathrm{CH}_{2}\right), 1.97\left(\mathrm{~s}, 9 \mathrm{H}, \mathrm{Bu}^{t}\right), 1.67-1.57(\mathrm{~m}$, $\left.2 \mathrm{H}, \mathrm{CH}_{2}\right), 1.44\left(\mathrm{~s}, 9 \mathrm{H}, \mathrm{Bu}^{\mathrm{t}}\right), 1.43-1.34\left(\mathrm{~m}, 8 \mathrm{H}, \mathrm{CH}_{2}+\mathrm{Me}\right), 0.90(\mathrm{t}, J$ $=7.3 \mathrm{~Hz}, 3 \mathrm{H}, \mathrm{Me}), 0.81-0.68\left(\mathrm{~m}, 2 \mathrm{H}, \mathrm{CH}_{2}\right), 0.52-0.43(\mathrm{~m}, 2 \mathrm{H}$, $\left.\mathrm{CH}_{2}\right) \cdot{ }^{13} \mathrm{C}$ NMR $\left(101 \mathrm{MHz}, \mathrm{C}_{6} \mathrm{D}_{6}\right): \delta 164.06,162.53,161.59$, 141.30, 141.05, 140.18, 138.24, 137.58, 136.75, 128.97, 126.76, $125.70,125.17,125.07,124.86,124.61,123.44,120.78,36.70$, $36.18,34.50,32.37,31.96,30.35,23.33,14.22,11.71,6.50$.

\section{Synthesis of $2 \mathrm{e}$}

A solution of $\mathbf{1 b}(0.23 \mathrm{~g}, 0.6 \mathrm{mmol})$ in toluene $\left(15 \mathrm{~cm}^{3}\right)$ was cooled to $0{ }^{\circ} \mathrm{C}$. A solution of $\mathrm{AlBu}_{3}{ }^{i}\left(0.65 \mathrm{~cm}^{3}, 1.1 \mathrm{M}\right.$ solution in hexane, $0.72 \mathrm{mmol}$ ) was added to the cooled solution. The resultant mixture was warmed to room temperature and stirred overnight. The solution was filtered and the filtrate was concentrated to afford red crystalline solid of $2 \mathrm{e}(0.198 \mathrm{~g}$, 62.9\%). Anal. calcd for $\mathrm{C}_{34} \mathrm{H}_{45} \mathrm{AlN}_{2} \mathrm{O}: \mathrm{C}, 77.83 ; \mathrm{H}, 8.64 ; \mathrm{N}$, 5.34\%. Found: C, $77.57 \mathrm{H}, 8.95 ; \mathrm{N}, 5.21 .{ }^{1} \mathrm{H}$ NMR $(400 \mathrm{MHz}$, $\left.\mathrm{C}_{6} \mathrm{D}_{6}\right): \delta 8.71(\mathrm{dd}, J=4.7,1.4 \mathrm{~Hz}, 1 \mathrm{H}, \mathrm{Ar}), 7.82(\mathrm{~d}, J=2.5 \mathrm{~Hz}, 1 \mathrm{H}$, Ar), $7.66(\mathrm{~d}, J=8.9 \mathrm{~Hz}, 1 \mathrm{H}, \mathrm{Ar}), 7.56(\mathrm{~d}, J=2.3 \mathrm{~Hz}, 1 \mathrm{H}, \mathrm{Ar}), 7.29$ $(\mathrm{t}, J=8.8 \mathrm{~Hz}, 2 \mathrm{H}, \mathrm{Ar}), 6.98-6.92(\mathrm{~m}, 2 \mathrm{H}, \mathrm{Ar}), 6.77$ (dd, $J=8.1$, $4.7 \mathrm{~Hz}, 1 \mathrm{H}, \mathrm{Ar}), 2.13-2.01(\mathrm{~m}, 2 \mathrm{H}, \mathrm{CH}), 1.97\left(\mathrm{~s}, 9 \mathrm{H}, \mathrm{Bu}^{t}\right), 1.42(\mathrm{~s}$, 9H, Bu $\left.{ }^{t}\right), 1.13(\mathrm{~d}, J=6.5 \mathrm{~Hz}, 6 \mathrm{H}, \mathrm{Me}), 1.02(\mathrm{~d}, J=6.5 \mathrm{~Hz}, 6 \mathrm{H}$, $\mathrm{Me}), 0.75\left(\mathrm{dd}, J=13.2,7.5 \mathrm{~Hz}, 2 \mathrm{H}, \mathrm{CH}_{2}\right), 0.48(\mathrm{dd}, J=13.2$, $\left.6.5 \mathrm{~Hz}, 2 \mathrm{H}, \mathrm{CH}_{2}\right) .{ }^{13} \mathrm{C}$ NMR $\left(101 \mathrm{MHz}, \mathrm{C}_{6} \mathrm{D}_{6}\right): \delta 164.15,162.01$, 146.68, 141.72, 140.67, 140.19, 137.90, 137.42, 136.72, 129.34, 127.94, 126.13, 125.48, 124.83, 124.29, 123.94, 123.26, 119.75, $36.12,34.49,31.89,30.50,29.46,29.27,29.01,27.63,24.87$.

\section{Synthesis of $2 \mathrm{f}$}

A solution of $\mathbf{1 b}(0.23 \mathrm{~g}, 0.60 \mathrm{mmol})$ in toluene $\left(15 \mathrm{~cm}^{3}\right)$ was cooled to $0{ }^{\circ} \mathrm{C}_{\text {. }} \mathrm{AlEt}_{3}\left(1.1 \mathrm{~cm}^{3}, 0.6 \mathrm{M}\right.$ solution in heptane, 0.66 $\mathrm{mmol}$ ) was added dropwise to the cooled solution. The resultant mixture was warmed to room temperature and stirred $8 \mathrm{~h}$. $\mathrm{BnOH}\left(0.156 \mathrm{~cm}^{3} 1.5 \mathrm{mmol}\right)$ was added to the solution. The resultant mixture was stirred overnight. The color of the solution changed from deep red to light yellow. Solvents were removed in vacuo and the residue was dissolved in diethyl ether. The solution was filtered and the filtrate was concentrated to afford yellow crystalline solid $(0.24 \mathrm{~g}, 64 \%)$. Anal. calcd for $\mathrm{C}_{40} \mathrm{H}_{41} \mathrm{AlN}_{2} \mathrm{O}_{3} \cdot 0.4 \mathrm{C}_{4} \mathrm{H}_{10} \mathrm{O}: \mathrm{C}, 76.35 ; \mathrm{H}, 6.93 ; \mathrm{N}, 4.28 \%$. Found: C, $76.33 \mathrm{H}, 6.93 ; \mathrm{N}, 4.19 .{ }^{1} \mathrm{H}$ NMR $\left(400 \mathrm{MHz}, \mathrm{CDCl}_{3}\right): \delta 9.56-9.40$ $(\mathrm{m}, 1 \mathrm{H}, \mathrm{Ar}), 8.45(\mathrm{~d}, J=8.0 \mathrm{~Hz}, 1 \mathrm{H}, \mathrm{Ar}), 8.33(\mathrm{~d}, J=8.8 \mathrm{~Hz}, 1 \mathrm{H}$, Ar), $8.28(\mathrm{~d}, J=8.9 \mathrm{~Hz}, 1 \mathrm{H}, \mathrm{Ar}), 7.89-7.78(\mathrm{~m}, 3 \mathrm{H}, \mathrm{Ar}), 7.62(\mathrm{~s}, 1 \mathrm{H}$,
Ar), 7.59 (s, 1H, Ar), 7.10 (b, 4H, Ar), 7.02 (b, 6H, Ar), 5.05 (s, 2H), $4.88(\mathrm{~s}, 2 \mathrm{H}), 3.47\left(\mathrm{q}, J=7.0 \mathrm{~Hz}, \mathrm{Et}_{2} \mathrm{O}\right), 1.60\left(\mathrm{~s}, 9 \mathrm{H}, \mathrm{Bu}^{t}\right), 1.41(\mathrm{~s}$, 9H, $\left.\mathrm{Bu}^{t}\right), 1.21\left(\mathrm{t}, J=7.0 \mathrm{~Hz}, \mathrm{Et}_{2} \mathrm{O}\right) .{ }^{13} \mathrm{C} \mathrm{NMR}\left(101 \mathrm{MHz}, \mathrm{CDCl}_{3}\right)$ : $\delta 162.63,160.31,149.89,141.31,139.52,139.21,138.74,138.13$, 138.03, 129.70, 127.79, 127.60, 126.26, 126.18, 125.53, 125.01, $124.97,124.46,124.37,122.75,118.43,66.01,65.86,35.85$, $34.50,31.74,30.03,15.44$.

\section{Polymerization of $\varepsilon$-caprolactone}

A typical polymerization procedure was exemplified using $\mathbf{2 a} /$ $\mathrm{BnOH}$ as the catalyst. Complex $2 \mathrm{a}(24.5 \mathrm{mg}, 0.0594 \mathrm{mmol})$ was dissolved in toluene $\left(5.4 \mathrm{~cm}^{3}\right)$ at $50{ }^{\circ} \mathrm{C}$. To the stirred solution $\mathrm{BnOH}\left(0.60 \mathrm{~cm}^{3}, 0.1 \mathrm{M}\right.$ solution in toluene, $\left.0.06 \mathrm{mmol}\right)$ and $\varepsilon-\mathrm{CL}$ $\left(0.63 \mathrm{~cm}^{3}, 5.94 \mathrm{mmol}\right)$ were successively added. The polymerization reaction was terminated after $5 \mathrm{~h}$ by addition of several drops of glacial acetic acid. The mixture was stirred at room temperature for $30 \mathrm{~min}$. The resulting solution was dropped into cool methanol with stirring. The white precipitate was filtered under reduced pressure and washed with cool methanol. For GPC analysis, the sample was dissolved in THF, passed through a short neutral aluminum oxide column, precipitated in methanol, and dried under vacuum.

Polymerization of rac- $\beta$-BL followed the same procedure as for the ROP of $\varepsilon$-CL.

\section{Polymerization of rac-lactide}

A typical polymerization procedure was exemplified using 2a/ $\mathrm{BnOH}$ as the catalyst. Complex $2 \mathrm{a}(19.0 \mathrm{mg}, 0.046 \mathrm{mmol})$ and $\mathrm{BnOH}\left(0.46 \mathrm{~cm}^{3}, 0.1 \mathrm{M}\right.$ solution in toluene, $\left.0.046 \mathrm{mmol}\right)$ were added in sequence into toluene $\left(2.0 \mathrm{~cm}^{3}\right)$. The resulting mixture was added to a stirred mixture of $r a c-\mathrm{LA}(0.66 \mathrm{~g}, 4.60 \mathrm{mmol})$ and

Table 5 Details of the X-ray structure determination of complex 2c
Complex

Empirical formula

fw

Crystal system

Space group

$a(\AA)$

$b(\AA)$

$c(\AA)$

$\alpha$ (deg)

$\beta$ (deg)

$\gamma(\mathrm{deg})$

$V\left(\AA^{3}\right)$

$Z$

$D_{\text {calcd }}\left(\mathrm{g} \mathrm{cm}^{-3}\right)$

$F(000)$

$\mu\left(\mathrm{mm}^{-1}\right)$

$\theta$ range for data collecn (deg)

No. of reflns collected

No. of indep reflns $\left(R_{\text {int }}\right)$

Restraints/params

Goodness of fit on $F^{2}$

Final $R$ indices $^{a}[I>2 \sigma(I)]$

$R$ indices (all data)

Largest diff peak and hole $\left[\mathrm{e} \AA^{-3}\right]$
${ }^{a} R_{1}=\sum|| F_{\mathrm{o}}|-| F_{\mathrm{c}}|| / \sum\left|F_{\mathrm{o}}\right|, \mathrm{w} R_{2}=\left[\sum \mathrm{w}\left(F_{\mathrm{o}}{ }^{2}-F_{\mathrm{c}}{ }^{2} / \sum \mathrm{w}\left(F_{\mathrm{o}}{ }^{4}\right)\right]^{1 / 2}\right.$.

$2 \mathrm{c} \cdot \mathrm{C}_{7} \mathrm{H}_{8}$
$\mathrm{C}_{47} \mathrm{H}_{49} \mathrm{~N}_{2} \mathrm{OAl}$
684.86
Monoclinic
$P 2_{(1)} / n$
$13.1762(12)$
$12.9320(11)$
$23.471(2)$
90
$96.3170(10)$
90
$3975.1(6)$
4
1.144
1464
0.088
2.21 to 25.02
19732
$6997\left(R_{\text {int }}=0.0910\right)$
$0 / 532$
1.019
$R_{1}=0.0596, \mathrm{w} R_{2}=0.0853$
$R_{1}=0.1763, \mathrm{w} R_{2}=0.0980$
0.156 and -0.159


toluene $\left(2.1 \mathrm{~cm}^{3}\right)$ at $70{ }^{\circ} \mathrm{C}$. The polymerization reaction was terminated after $24 \mathrm{~h}$ by adding several drops of glacial acetic acid. The mixture was stirred at room temperature for $30 \mathrm{~min}$. The resulting solution was dropped into cool methanol with stirring. The white precipitate was filtered under reduced pressure and washed with cool methanol. For GPC analysis, the sample was dissolved in THF, passed through a short neutral aluminum oxide column, precipitated in methanol, and dried under vacuum.

\section{X-ray crystallography}

Single crystals of complex 2c were mounted in Lindemann capillaries under $\mathrm{N}_{2}$. Diffraction data were collected at 298(2) K on a Bruker Smart CCD area detector with graphitemonochromated Mo $\mathrm{K} \alpha$ radiation $(\lambda=0.71073 \AA)$. The structure was solved by direct methods using SHELXS-97 (ref. 20) and refined against $F^{2}$ by full-matrix least squares using SHELXL97. ${ }^{21}$ Hydrogen atoms were placed in calculated positions. Crystal data and experimental details of the structure determination are listed in Table 5.

\section{Acknowledgements}

We thank the Foundation for Talents of Anhui Province (Grant No. 2008Z011) for financial support. We also thank Professor D.-Q. Wang for the crystal structure determination.

\section{Notes and references}

1 (a) J. C. Wu, T. L. Yu, C. T. Chen and C. C. Lin, Coord. Chem. Rev., 2006, 250, 602-626; (b) G.-Q. Chen, Chem. Soc. Rev., 2009, 38, 2434-2446; (c) T. K. Dash and V. B. Konkimalla, J. Controlled Release, 2012, 158, 15-33; (d) R. A. Cairncross, J. G. Becker, S. Ramaswamy and R. O'Connor, Appl. Biochem. Biotechnol., 2006, 131, 774-785; (e) R. Auras, B. Harte and S. Selke, Macromol. Biosci., 2004, 4, 835-864; (f) S. Farah, D. G. Anderson and R. Langer, Adv. Drug Delivery Rev., 2016, 107, 367-392; (g) C. M. Thomas, Chem. Soc. Rev., 2010, 39, 165-173; (h) Y. Q. Zhu, C. Romain and C. K. Williams, Nature, 2016, 540, 354-362; (i) N. Spassky, M. Wisniewski, C. Pluta and A. LeBorgne, Macromol. Chem. Phys., 1996, 197, 2627-2637; (j) Z. Zhong, P. J. Dijkstra and J. Feijen, Angew. Chem., Int. Ed., 2002, 41, 4510-4513; (k) Z. Zhong, P. J. Dijkstra and J. Feijen, J. Am. Chem. Soc., 2003, 125, 11291-11298; (l) Z. Tang, X. Chen, X. Pang, Y. Yang, X. Zhang and X. Jing, Biomacromolecules, 2004, 5, 965-970; $(m)$ N. Nomura, R. Ishii, Y. Yamamoto and T. Kondo, Chem.-Eur. J., 2007, 13, 4433-4451; (n) X. Pang, R. Duan, X. Li, Z. Sun, H. Zhang, X. Wang and X. Chen, Polym. Chem., 2014, 5, 6857-6864; (o) N. Nomura, A. Akita, R. Ishii and M. Mizuno, J. Am. Chem. Soc., 2010, 132, 17501751; (p) G. Li, M. Lamberti, D. Pappalardo and C. Pellecchia, Macromolecules, 2012, 45, 8614-8620; (q) Y. Wang and H. Ma, Chem. Commun., 2012, 48, 6729-6731; (r) L. Li, B. Liu, D. Liu, C. Wu, S. Li, B. Liu and D. Cui, Organometallics, 2014, 33, 6474-6480; $(s)$ A. Pilone, N. De
Maio, K. Press, V. Venditto, D. Pappalardo, M. Mazzeo, C. Pellecchia, M. Kol and M. Lamberti, Dalton Trans., 2015, 44, 2157-2165; $(t)$ W. Li, H. Ouyang, L. Chen, D. Yuan, Y. Zhang and Y. Yao, Inorg. Chem., 2016, 55, 6520-6524; $(u)$ X. Wang, V. Dorcet, Y. Luo, J.-F. Carpentier and E. Kirillov, Dalton Trans., 2016, 45, 12346-12351; (v) C.-Y. Hsu, H.-C. Tseng, J. K. Vandavasi, W.-Y. Lu, L.-F. Wang, M. Y. Chiang, Y.-C. Lai, H.-Y. Chen and H.-Y. Chen, RSC Adv., 2017, 7, 18851-18860; (w) J. Zhang, S. Liu, W. Zuo, H. Ye and Z. Li, New J. Chem., 2017, 41, 2358-2363.

2 (a) M. J. Stanford and A. P. Dove, Chem. Soc. Rev., 2010, 39, 486-494; (b) R. H. Platel, L. M. Hodgson and C. K. Williams, Polym. Rev., 2008, 48, 11-63; (c) P. J. Dijkstra, H. Du and J. Feijen, Polym. Chem., 2011, 2, 520-527; (d) L. T. Lim, R. Auras and M. Rubino, Prog. Polym. Sci., 2008, 33, 820-852.

3 M. Labet and W. Thielemans, Chem. Soc. Rev., 2009, 38, 3484-3504.

4 J.-F. Carpentier, Macromol. Rapid Commun., 2010, 31, 16961705.

5 (a) Y. Sun, J. Xiong, Z. Dai, X. Pan, N. Tang and J. Wu, Inorg. Chem., 2016, 55, 136-143; (b) W.-J. Chuang, Y.-T. Huang, Y.-H. Chen, Y.-S. Lin, W.-Y. Lu, Y.-C. Lai, M. Y. Chiang, S. C. N. Hsu and H.-Y. Chen, RSC Adv., 2016, 6, 3301433021; (c) H.-W. Ou, K.-H. Lo, W.-T. Du, W.-Y. Lu, W.-J. Chuang, B.-H. Huang, H.-Y. Chen and C.-C. Lin, Inorg. Chem., 2016, 55, 1423-1432; (d) F. M. Garcia-Valle, R. Estivill, C. Gallegos, T. Cuenca, M. E. G. Mosquera, V. Tabernero and J. Cano, Organometallics, 2015, 34, 477487; (e) D. Alhashmialameer, N. Ikpo, J. Collins, L. N. Dawe, K. Hattenhauer and F. M. Kerton, Dalton Trans., 2015, 44, 20216-20231; (f) R. K. Dean, A. M. Reckling, H. Chen, L. N. Dawe, C. M. Schneider and C. M. Kozak, Dalton Trans., 2013, 42, 3504-3520; $(g)$ S.-C. Rosca, D.-A. Rosca, V. Dorcet, C. M. Kozak, F. M. Kerton, J.-F. Carpentier and Y. Sarazin, Dalton Trans., 2013, 42, 9361-9375; (h) H.-Y. Chen, L. Mialon, K. A. Abboud and S. A. Miller, Organometallics, 2012, 31, 5252-5261; ( $i$ ) J. Zhang, C. Jian, Y. Gao, L. Wang, N. Tang and J. Wu, Inorg. Chem., 2012, 51, 13380-13389; (j) W.-Y. Lu, M.-W. Hsiao, S. C. N. Hsu, W.-T. Peng, Y.-J. Chang, Y.-C. Tsou, T.-Y. Wu, Y.-C. Lai, Y. Chen and H.-Y. Chen, Dalton Trans., 2012, 41, 3659-3667; (k) N. Ikpo, C. Hoffmann, L. N. Dawe and F. M. Kerton, Dalton Trans., 2012, 41, 6651-6660; (l) B. Calvo, M. G. Davidson and D. Garcia-Vivo, Inorg. Chem., 2011, 50, 3589-3595; $(\mathrm{m})$ Y. Huang, Y.-H. Tsai, W.-C. Hung, C.-S. Lin, W. Wang, J.-H. Huang, S. Dutta and C.-C. Lin, Inorg. Chem., 2010, 49, 9416-9425; (n) A. K. Sutar, T. Maharana, S. Dutta, C.-T. Chen and C.-C. Lin, Chem. Soc. Rev., 2010, 39, 17241746; (o) B. T. Ko and C. C. Lin, J. Am. Chem. Soc., 2001, 123, 7973-7977.

6 (a) M. G. Cushion and P. Mountford, Chem. Commun., 2011, 47, 2276-2278; (b) J. P. Davin, J.-C. Buffet, T. P. Spaniol and J. Okuda, Dalton Trans., 2012, 41, 12612-12618; (c) Y. Sarazin, B. Liu, T. Roisnel, L. Maron and J.-F. Carpentier, J. Am. Chem. Soc., 2011, 133, 9069-9087; 
(d) M.-W. Hsiao and C.-C. Lin, Dalton Trans., 2013, 42, 20412051; (e) H.-Y. Chen, H.-Y. Tang and C.-C. Lin, Polymer, 2007, 48, 2257-2262; $(f)$ Y. Wang, W. Zhao, X. Liu, D. Cui and E. Y. X. Chen, Macromolecules, 2012, 45, 6957-6965; $(g)$ T. Rosen, I. Goldberg, V. Venditto and M. Kol, J. Am. Chem. Soc., 2016, 138, 12041-12044; (h) W. Yi and H. Ma, Dalton Trans., 2014, 43, 5200-5210; (i) L. Wang and H. Ma, Macromolecules, 2010, 43, 6535-6537; (j) H. Xie, Z. Mou, B. Liu, P. Li, W. Rong, S. Li and D. Cui, Organometallics, 2014, 33, 722-730; (k) J. Wu, Y.-Z. Chen, W.-C. Hung and C.-C. Lin, Organometallics, 2008, 27, 4970-4978; (l) L. F. Sanchez-Barba, A. Garces, M. Fajardo, C. AlonsoMoreno, J. Fernandez-Baeza, A. Otero, A. Antinolo, J. Tejeda, A. Lara-Sanchez and M. I. Lopez-Solera, Organometallics, 2007, 26, 6403-6411; $\quad(m)$ B. M. Chamberlain, M. Cheng, D. R. Moore, T. M. Ovitt, E. B. Lobkovsky and G. W. Coates, J. Am. Chem. Soc., 2001, 123, 3229-3238.

7 (a) S. Ghosh, R. R. Gowda, R. Jagan and D. Chakraborty, Dalton Trans., 2015, 44, 10410-10422; (b) P. Horeglad, M. Cybularczyk, A. Litwinska, A. M. Dabrowska, M. Dranka, G. Z. Zukowska, M. Urbanczyk and M. Michalak, Polym. Chem., 2016, 7, 2022-2036; (c) F. Hild, N. Neehaul, F. Bier, M. Wirsum, C. Gourlaouen and S. Dagorne, Organometallics, 2013, 32, 587-598; (d) I. Yu, A. AcostaRamirez and P. Mehrkhodavandi, J. Am. Chem. Soc., 2012, 134, 12758-12773; (e) D. C. Aluthge, J. M. Ahn and P. Mehrkhodavandi, Chem. Sci., 2015, 6, 5284-5292; (f) A. F. Douglas, B. O. Patrick and P. Mehrkhodavandi, Angew. Chem., Int. Ed., 2008, 47, 2290-2293; $(g)$ N. Maudoux, T. Roisnel, V. Dorcet, J.-F. Carpentier and Y. Sarazin, Chem.-Eur. J., 2014, 20, 6131-6147; (h) M. Normand, T. Roisnel, J. F. Carpentier and E. Kirillov, Chem. Commun., 2013, 49, 11692-11694; (i) A. Pietrangelo, M. A. Hillmyer and W. B. Tolman, Chem. Commun., 2009, 2736-2737; (j) M. Normand, V. Dorcet, E. Kirillov and J.-F. Carpentier, Organometallics, 2013, 32, 1694-1709; $(k)$ Y.-L. Hsieh, N. Huang, G.-H. Lee and C.-H. Peng, Polymer, 2015, 72, 281-291; (l) B.-H. Huang, C.-Y. Tsai, C.-T. Chen and B.-T. Ko, Dalton Trans., 2016, 45, 17557-17580; $(\mathrm{m})$ Y. Wei, S.-W. Wang and S.-L. Zhou, Dalton Trans., 2016, 45, 4471-4485.

8 (a) V. Poirier, T. Roisnel, S. Sinbandhit, M. Bochmann, J.-F. Carpentier and Y. Sarazin, Chem.-Eur. J., 2012, 18, 2998-3013; (b) L. Wang, S.-C. Rosca, V. Poirier, S. Sinbandhit, V. Dorcet, T. Roisnel, J.-F. Carpentier and Y. Sarazin, Dalton Trans., 2014, 43, 4268-4286; (c) W.-A. Ma and Z.-X. Wang, Dalton Trans., 2011, 40, 1778-1786; (d) A. J. Chmura, C. J. Chuck, M. G. Davidson, M. D. Jones, M. D. Lunn, S. D. Bull and M. F. Mahon, Angew. Chem., Int. Ed., 2007, 46, 2280-2283; (e) J. Guo, P. Haquette, J. Martin, K. Salim and C. M. Thomas, Angew. Chem., Int. Ed., 2013, 52, 13584-13587.

9 (a) Y.-L. Duan, J.-X. He, W. Wang, J.-J. Zhou, Y. Huang and Y. Yang, Dalton Trans., 2016, 45, 10807-10820; (b) N. Ajellal, D. M. Lyubov, M. A. Sinenkov, G. K. Fukin, A. V. Cherkasov, C. M. Thomas, J.-F. Carpentier and
A. A. Trifonov, Chem.-Eur. J., 2008, 14, 5440-5448; (c) J. Jenter, P. W. Roesky, N. Ajellal, S. M. Guillaume, N. Susperregui and L. Maron, Chem.-Eur. J., 2010, 16, 4629-4638; (d) H. Ma, T. P. Spaniol and J. Okuda, Inorg. Chem., 2008, 47, 3328-3339; (e) Y. Cui, W. Gu, Y. Wang, B. Zhao, Y. Yao and Q. Shen, Catal. Sci. Technol., 2015, 5, 3302-3312; (f) W. Gu, P. Xu, Y. Wang, Y. Yao, D. Yuan and Q. Shen, Organometallics, 2015, 34, 2907-2916; $(g)$ Z. Mou, B. Liu, X. Liu, H. Xie, W. Rong, L. Li, S. Li and D. Cui, Macromolecules, 2014, 47, 2233-2241; (h) C. Bakewell, A. J. P. White, N. J. Long and C. K. Williams, Angew. Chem., Int. Ed., 2014, 53, 9226-9230; (i) C. Bakewell, C. ThiPhuong-Anh, N. Long, X. F. Le Goff, A. Auffrant and C. K. Williams, J. Am. Chem. Soc., 2012, 134, 20577-20580; (j) J.-F. Carpentier, Organometallics, 2015, 34, 4175-4189.

10 (a) A. B. Biernesser, K. R. Delle Chiaie, J. B. Curley and J. A. Byers, Angew. Chem., Int. Ed., 2016, 55, 5251-5254; (b) A. B. Biernesser, B. Li and J. A. Byers, J. Am. Chem. Soc., 2013, 135, 16553-16560; (c) S. Fortun, P. Daneshmand and F. Schaper, Angew. Chem., Int. Ed., 2015, 54, 13669-13672; (d) D. Mandal, D. Chakraborty, V. Ramkumar and D. K. Chand, RSC Adv., 2016, 6, 21706-21718; (e) A. J. Chmura, M. G. Davidson, M. D. Jones, M. D. Lunn, M. F. Mahon, A. F. Johnson, P. Khunkamchoo, S. L. Roberts and S. S. F. Wong, Macromolecules, 2006, 39, 7250-7257; ( $f$ ) A. Sauer, A. Kapelski, C. Fliedel, S. Dagorne, M. Kol and J. Okuda, Dalton Trans., 2013, 42, 9007-9023; (g) X.-X. Zheng, C. Zhang and Z.-X. Wang, J. Organomet. Chem., 2015, 783, 105-115; (h) M. Honrado, A. Otero, J. Fernandez-Baeza, L. F. Sanchez-Barba, A. Garces, A. LaraSanchez and A. M. Rodriguez, Dalton Trans., 2014, 43, 17090-17100; ( $i$ ) Y. Yang, H. Wang and H. Ma, Inorg. Chem., 2015, 54, 5839-5854; (j) X.-F. Yu, C. Zhang and Z.-X. Wang, Organometallics, 2013, 32, 3262-3268; (k) S. Abbina and G. Du, ACS Macro Lett., 2014, 3, 689-692; (l) C. K. Williams, L. E. Breyfogle, S. K. Choi, W. Nam, V. G. Young, M. A. Hillmyer and W. B. Tolman, J. Am. Chem. Soc., 2003, 125, 11350-11359; ( $m$ ) M. Cheng, A. B. Attygalle, E. B. Lobkovsky and G. W. Coates, J. Am. Chem. Soc., 1999, 121, 11583-11584.

11 (a) D. Pappalardo, L. Annunziata and C. Pellecchia, Macromolecules, 2009, 42, 6056-6062; (b) L. Chen, W. Li, D. Yuan, Y. Zhang, Q. Shen and Y. Yao, Inorg. Chem., 2015, 54, 4699-4708; (c) W.-L. Kong and Z.-X. Wang, Dalton Trans., 2014, 43, 9126-9135; (d) J. S. Klitzke, T. Roisnel, E. Kirillov, O. d. L. Casagrande Jr and J.-F. Carpentier, Organometallics, 2014, 33, 309-321; (e) W.-H. Sun, M. Shen, W. Zhang, W. Huang, S. Liu and C. Redshaw, Dalton Trans., 2011, 40, 2645-2653; (f) H.-C. Tseng, M. Y. Chiang, W.-Y. Lu, Y.-J. Chen, C.-J. Lian, Y.-H. Chen, H.-Y. Tsai, Y.-C. Lai and H.-Y. Chen, Dalton Trans., 2015, 44, 1176311773; $(g)$ K. Press, I. Goldberg and M. Kol, Angew. Chem., Int. Ed., 2015, 54, 14858-14861; (h) A. Pilone, K. Press, I. Goldberg, M. Kol, M. Mazzeo and M. Lamberti, J. Am. Chem. Soc., 2014, 136, 2940-2943; (i) S. Tabthong, T. Nanok, P. Sumrit, P. Kongsaeree, S. Prabpai, P. Chuawong and P. Hormnirun, Macromolecules, 2015, 48, 
6846-6861; (j) X. Pang, R. Duan, X. Li and X. Chen, Polym. Chem., 2014, 5, 3894-3900; (k) P. Hormnirun, E. L. Marshall, V. C. Gibson, A. J. P. White and D. J. Williams, J. Am. Chem. Soc., 2004, 126, 2688-2689; (l) T. M. Ovitt and G. W. Coates, J. Am. Chem. Soc., 2002, 124, 1316-1326; $(m)$ T. M. Ovitt and G. W. Coates, J. Am. Chem. Soc., 1999, 121, 4072-4073; (n) P. Wang, X. Hao, J. Cheng, J. Chao and X. Chen, Dalton Trans., 2016, 45, 9088-9096.

12 W.-L. Kong, Z.-Y. Chai and Z.-X. Wang, Dalton Trans., 2014, 43, 14470-14480.

13 R. Gebbink, M. Watanabe, R. C. Pratt and T. D. P. Stack, Chem. Commun., 2003, 630-631.

14 M. Save, M. Schappacher and A. Soum, Macromol. Chem. Phys., 2002, 203, 889-899.

15 (a) X. Pang, R. Duan, X. Li, Z. Sun, H. Zhang, X. Wang and X. Chen, RSC Adv., 2014, 4, 57210-57217; (b) N. Nomura, R. Ishii, M. Akakura and K. Aoi, J. Am. Chem. Soc., 2002, 124, 5938-5939.

16 (a) A. Meduri, T. Fuoco, M. Lamberti, C. Pellecchia and D. Pappalardo, Macromolecules, 2014, 47, 534-543; (b) C. M. Dong, K. Y. Qiu, Z. W. Gu and X. D. Feng, J. Polym. Sci., Part A: Polym. Chem., 2001, 39, 357-367.
17 (a) L. Liu, Z. Y. Wei and M. Qi, Chin. Chem. Lett., 2007, 18, 744-746; (b) X. Wang, J. Liu, S. Xu, J. Xu, X. Pan, J. Liu, S. Cui, Z. Li and K. Guo, Polym. Chem., 2016, 7, 6297-6308; (c) Y. Wang, B. Liu, X. Wang, W. Zhao, D. Liu, X. Liu and D. Cui, Polym. Chem., 2014, 5, 4580-4588.

18 (a) D. A. Jayawickrama, C. K. Larive, E. F. McCord and D. C. Roe, Magn. Reson. Chem., 1998, 36, 755-760; (b) C. F. Hansell, P. Espeel, M. M. Stamenović, I. A. Barker, A. P. Dove, F. E. D. Prez and R. K. O'Reilly, J. Am. Chem. Soc., 2011, 133, 13828-13831.

19 (a) T. Wang, F. Chen, J. Qin, Y.-M. He and Q.-H. Fan, Angew. Chem., Int. Ed., 2013, 52, 7172-7176; (b) F. Della Monica, E. Luciano, G. Roviello, A. Grassi, S. Milione and C. Capacchione, Macromolecules, 2014, 47, 2830-2841; (c) L. F. Tietze, T. Hungerland, A. Duefert, I. Objartel and D. Stalke, Chem.-Eur. J., 2012, 18, 3286-3291; (d) T.-Q. Xu, W. Gao, Y. Mu and L. Ye, Polyhedron, 2007, 26, 3357-3362. 20 G. M. Sheldrick, Acta Crystallogr., Sect. A: Found. Crystallogr., 1990, 46, 467-473.

21 G. M. Sheldrick, SHELXL97: Programs for Structure Refinement, Universität Göttingen, Gösttingen, Germany, 1997. 